\title{
Onorden
}

\section{Mushrooms traded as food}

Nordic questionnaire, including guidance list on edible mushrooms suitable and not suitable for marketing. For industry, trade and food inspection

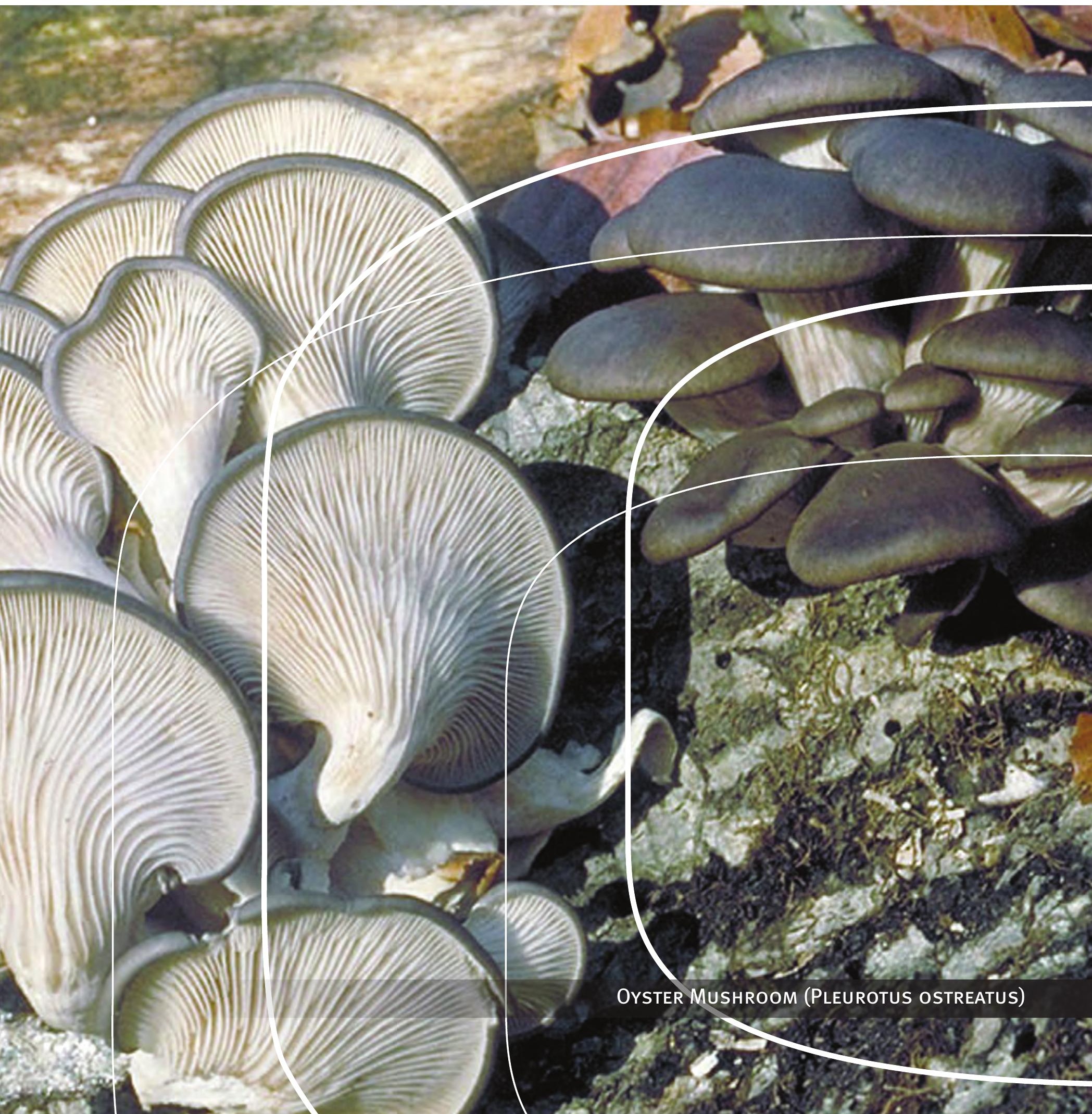



4 norden 



\section{Mushrooms traded as food}

Nordic questionnaire, including guidance list on edible mushrooms suitable and not suitable for marketing. For industry, trade and food inspection

Jørn Gry (consultant), Denmark, Christer Andersson, National Food Administration, Sweden, Lulu Krüger, Danish Veterinary and Food Administration, Birgitte Lyrån and Laila Jensvoll, Norwegian Food Safety Authority, Niina Matilainen and Annika Nurttila, Finnish Food Safety Authority Evira, Finland, Grímur Olafsson, Public Health Authority of Hafnarfjörður and Kópavogur, Iceland and Bente Fabech, Danish Veterinary and Food Administration (chairperson) 
Mushrooms traded as food

Nordic questionnaire, including guidance list on edible mushrooms

suitable and not suitable for marketing. For industry, trade and food inspection

Jørn Gry (consultant), Denmark, Christer Andersson, National Food Administration, Sweden,

Lulu Krüger, Danish Veterinary and Food Administration, Birgitte Lyrån and Laila Jensvoll,

Norwegian Food Safety Authority, Niina Matilainen and Annika Nurttila, Finnish Food Safety

Authority Evira, Finland, Grímur Olafsson, Public Health Authority of Hafnarfjörður and

Kópavogur, Iceland and Bente Fabech, Danish Veterinary and Food Administration (chairperson)

TemaNord 2012:542

ISBN 978-92-893-2382-6

http://dx.doi.org/10.6027/TN2012-542

(C) Nordic Council of Ministers 2012

Cover photo: Jens H. Petersen

Photo: Jens H. Petersen; Thomas Stjernegaard Jeppesen; Henning Knudsen; Ole Sparre Pedersen; Jan Vesterholt

This publication has been published with financial support by the Nordic Council of Ministers. However, the contents of this publication do not necessarily reflect the views, policies or recommendations of the Nordic Council of Ministers.

www.norden.org/en/publications

Nordic co-operation

Nordic co-operation is one of the world's most extensive forms of regional collaboration, involving Denmark, Finland, Iceland, Norway, Sweden, and the Faroe Islands, Greenland, and Åland.

Nordic co-operation has firm traditions in politics, the economy, and culture. It plays an important role in European and international collaboration, and aims at creating a strong Nordic community in a strong Europe.

Nordic co-operation seeks to safeguard Nordic and regional interests and principles in the global community. Common Nordic values help the region solidify its position as one of the world's most innovative and competitive.

\section{Nordic Council of Ministers}

Ved Stranden 18

DK-1061 Copenhagen $\mathrm{K}$

Phone (+45) 33960200

www.norden.org 


\section{Content}

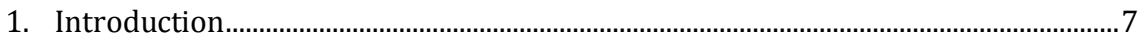

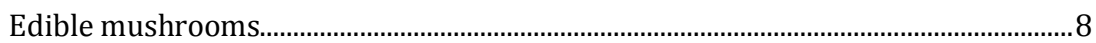

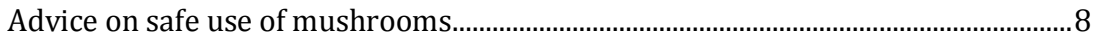

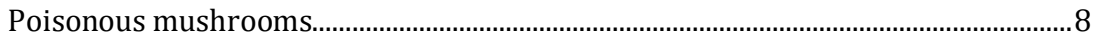

2. Questionnaire and guidance lists on mushrooms suitable and not suitable as food in trade and industry.................................................................................... 11

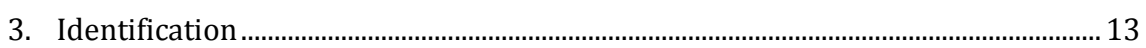

4. Legislation and in-house control and documentation.............................................. 15 Questionnaire for the control by industry, trade and the food inspection ............. 16

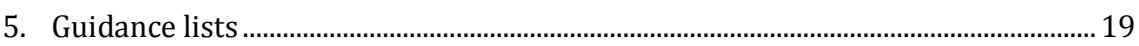

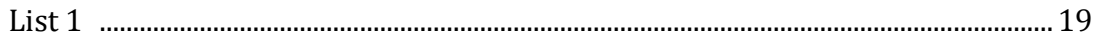

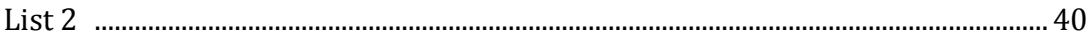

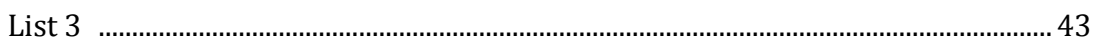

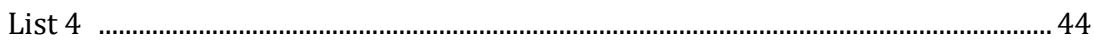

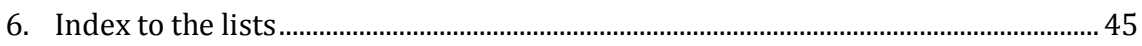

Annex I - Overview on relevant EU and national legislation and in-house

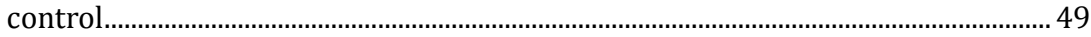

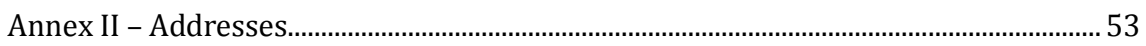





\section{Introduction}

Mushrooms are traditionally used as foodstuffs, both commercially and privately. Some edible mushrooms are cultivated like Oyster Mushroom and Button Mushroom, while others like Chanterelle and Cep are growing wild and collected in the nature. Both the cultivated and the wild mushrooms are commercially available.

Mushrooms are sold fresh or as products like dried, edible fungi (including freeze-dried fungi, fungus grits, fungus powder), pickled fungi, salted fungi, fermented fungi, fungi in vegetable oils, quick frozen fungi, sterilized fungi, fungus extract, fungus concentrate and dried fungus concentrate or as ingredients of foods ready-to-eat.

This project is focusing on mushrooms sold commercially as food. It is the aim to give guidance on edible mushrooms to industry and trade and to the public food inspection. ${ }^{1}$

The guiding tools are a questionnaire and as support, guidance lists on mushrooms, based on risk assessments of published scientific research (Volume I).

More background information is available in the background report: Volume II, section 1 and 2.

Volume II, section 1 has also more details on mushrooms, contaminants, intoxications and legislation.

Volume II, section 2 covers the risk assessments on more than 100 individual species in the four lists with scientific references on which the assessments are based. Pictures of the mushrooms in lists are also included.

The goal for the publication is to improve the in-house control and thereby the safety of traded mushrooms as food.

\footnotetext{
${ }^{1}$ The questionnaire and the guidance lists are available in separate publications in Danish, Icelandic, Norwegian and Swedish as well as in English. The project group consists of the following persons:, Jørn Gry (consultant in food safety), Denmark; Christer Andersson, National Food Administration, Sweden; Lulu Krüger, Danish Veterinary and Food Administration, Birgitte Lyrån and Laila Jensvoll, Norwegian Food Safety Authority, Niina Matilainen and Annika Nuutilla, Finnish Food Safety Authority Evira, Finland; Grímur Olafsson, Public Health Authority of Hafnarfjörður and Kópavogur, Iceland and Bente Fabech, Danish Veterinary and Food Administration (chairperson). The Food inspectors and national mycological societies consulted are acknowledged in Volume II, section I, see www.norden.org
} 


\section{Edible mushrooms}

Edible mushrooms mean fruit bodies of fungi, a group of organisms different from plants and animals.

In general, mushrooms sold as edible should not harm the consumer, neither immediately nor with short-term or long-term adverse effects. This is the common ground in the EU legislation on food.

The European Food Law, Regulation (EC) No 178/2002 defines "food" (or "foodstuff") as "any substance or product, whether processed, partially processed or unprocessed, intended to be, or reasonably expected to be ingested by humans." Many mushroom species are only suitable for use as food after processing.

Knowledge of "what is edible" is essential and so is correct identification of mushrooms traded as food. Knowledge has to be updated as the available information of adverse effects after ingestion of some mushroom species is developing. Furthermore, the number of species sold as edible mushrooms seems to in-crease.

\section{Advice on safe use of mushrooms}

- Eat only mushrooms which you are $100 \%$ sure that you can recognize

- Eat only mushrooms, which are generally recognized as edible

- Do not eat mushrooms raw, as many mushrooms may cause discomfort, e.g. stomach pain if eaten raw

- Do not eat spoiled mushrooms

- When eating a new species of a mushroom for the first time, always start up with a small portion in order to minimize the possible risk for allergy or other hypersensitivity reactions

\section{Poisonous mushrooms}

Mushrooms cover both edible species, like Boletus species (e.g. Cep), and acutely or even deadly poisonous species like Deathcap (Amanita phalloides). Other species of mushrooms contain compounds, which may have long-term effects (e.g. induce tumours), or toxins that cause intoxications of less serious outcome. More common effects are nausea, stomach pain, and hypersensitivity reactions to mention a few effects. 
Thus, it is important to have a good overview of the local mushroom market. As the global interchange of foods is increasing, new mushroom species might appear on the Nordic market. All these issues require guidance for responsible in-house control in trade and industry as well as in the public food inspection in order to ensure food safety.

Whether food items are safe to eat or not is to large extent based on knowledge gathered during centuries. However, the assessment of food safety should be based on a modern approach to risk assessment based on data available in the scientific literature.

In Europe, foods that are new on the European market are covered by the Novel Food regulation. A short overview of relevant legislation is in Annex I. 



\section{Questionnaire and guidance lists on mushrooms suitable and not suitable as food in trade and industry}

The questionnaire and the guidance lists are tools for business operators, who have the responsibility to ensure both identification and safety of traded mushrooms. The lists are also meant to be a tool for the food inspection in guidance of in-house control.

\section{Questionnaire}

The questionnaire is to be used in the in-house control in trade and industry and by the public food inspection.

\section{Guidance lists}

The guidance lists 1 and 2 comprise edible mushrooms which are regarded as suitable for commercial marketing covering the most commonly traded mushrooms in most Nordic countries, and the guidance lists 3 and 4 comprise mushrooms that might be edible or have been reported as edible, but which are not considered as suitable for marketing, either because they may cause adverse effects or they are easily mistaken for poisonous mushrooms ("look-alikes").

All mushroom species listed in the guidance lists have been risk assessed taking into consideration published scientific information and other data available. These referenced risk assessments are available for each individual mushroom species in the background report (Volume II, section 2). To facilitate the use of these guiding lists appropriate pictures of the various mushroom species listed have been included in the list 1 . However, the appearance of a mushroom differs, so more tools should be used for safe identification.

The lists 1 and 2 cover mushrooms that are or may be traded in most Nordic countries, but the lists are not exhaustive. Mushrooms which are 
not on the lists 1 and 2 might be traded legally, if in compliance with the Food Regulation, but food inspectors should in these cases require risk assessment from the responsible business operators. Such risk assessments should cover scientific documentation equivalent to the guidance in Volume II or to the requirements in the Novel Food regulation.

Finland has national legislation ${ }^{2}$ on edible mushrooms suitable for marketing. All mushrooms collected or grown and mushroom products produced in Finland have to meet the requirements. There are about 24 different mushroom species on the list. In Finland it is only allowed to collect those mushrooms mentioned on the list for marketing purposes only. The legislation is not applicable for imported mushrooms.

2 Decree on Marketing of Mushrooms (489/2006) given by the Ministry on Trade and Industry. Based on this decree the Finnish Food Safety Authority Evira has given an Order "List of Mushrooms Suitable for Marketing" (3/2007). 


\section{Identification}

A correct identification of a mushroom species is a cornerstone in the risk assessment as it implies an evaluation of whether a specific mushroom is an edible species, a toxic species or maybe a "look-alike" to poisonous mushroom species.

Industry and trade responsible for selling mushrooms as foods must be able to clearly identify the species sold. For imported mushrooms, they have to have solid documentation from their suppliers in other countries, that the mushrooms sold are identified by people with appropriate knowledge. This is important also for all preparations of mushrooms, including the dried mushrooms. Identification requires special knowledge and expertise, especially the identification of dried mushrooms.

As some mushrooms are toxic, it is essential to know both the identity of the edible species and the none-edible "look-alikes" and other mushrooms.

Mushroom collectors in exporting countries and private collectors selling to restaurants must have the skills to identify the mushrooms and to distinguish them from not-edible or even poisonous mushrooms. ${ }^{3}$ Mycological training is essential for the identification.

Up-to-date information on mushroom identification is found in new handbooks, electronic media etc. and not at least by consulting mycological experts. See also Volume II section 1.

${ }^{3}$ This is given in the EU Hygiene Regulation (ref. Regulation (EC) No 852/2004; Annex 1, point 5d). 



\section{Legislation and in-house control and documentation}

A short overview on relevant EU and national legislation and a short introduction to in-house control in trade and industry are given in Annex I.

More detailed information and risk assessments of mushrooms in the four lists are in Volume II, see www.norden.org 


\section{Questionnaire for the control by industry, trade and the food inspection}

Company name and address

Person responsible for the control

Date for the control

\begin{tabular}{|c|c|c|c|}
\hline No & Check points & Answers & Comments \\
\hline 1 & Name of the product & & \\
\hline 2 & $\begin{array}{l}\text { Name and address of the supplier to the company } \\
\text { (traceability) }\end{array}$ & & \\
\hline 3 & $\begin{array}{l}\text { Authorisation, status: } \\
\text { Does the national legislation request authorisa- } \\
\text { tion/approval? } \\
\text { Is the supplier }{ }^{4} \text { authorized/approved by the food } \\
\text { control authority? }\end{array}$ & & \\
\hline 4 & $\begin{array}{l}\text { Country of origin } \\
\text { (Only a legal requirement for cultivated, fresh } \\
\text { mushrooms However, country of origin must } \\
\text { always be labelled if needed - e.g. if there is } \\
\text { doubt of the country of origin) }\end{array}$ & & \\
\hline 5 & $\begin{array}{l}\text { Traceability } \\
\text { (Clear connection between the product and its } \\
\text { documentation) }\end{array}$ & & \\
\hline 6 & $\begin{array}{l}\text { Labelling } \\
\text { Specific name in national language, including the } \\
\text { ingredient list for mixed mushrooms (Information: } \\
\text { See the guidance lists) }\end{array}$ & & \\
\hline 7 & $\begin{array}{l}\text { Is (are) the mushroom(s) included in the Nordic } \\
\text { lists } 1 \text { or } 2 \text { on edible mushrooms and documenta- } \\
\text { tion for identity available? }\end{array}$ & $\begin{array}{l}\text { If, yes, }- \text { go to point } \\
9 \text { and } 10 . \\
\text { If, no }- \text { go to point } 8 .\end{array}$ & \\
\hline
\end{tabular}

4 The supplier can be a producer or an importer/intercommunity trade. Private collectors are normally not requested to be registered, as they often only have a small business. However, they have to comply with the Food Law, article 14

${ }^{5}$ Finland has national legislation in force for mushrooms collected or grown in Finland. 


\begin{tabular}{|c|c|c|c|}
\hline No & Check points & Answers & Comments \\
\hline 8 & $\begin{array}{l}\text { Is (are) the mushroom(s) on the Nordic lists of } \\
\text { mushrooms not suitable for marketing (lists } 3 \text { or } 4) \text { ? }\end{array}$ & $\begin{array}{l}\text { If yes = not accepta- } \\
\text { ble for commercial } \\
\text { use } \\
\text { If no - Documenta- } \\
\text { tion for identity and } \\
\text { the assessment of } \\
\text { the status as edible } \\
\text { (Compliance with } \\
\text { article 14, EU Food } \\
\text { Law) } \\
\text { If the documentation } \\
\text { is accepted, then go } \\
\text { to point } 9 \text { and } 10\end{array}$ & \\
\hline 9 & $\begin{array}{l}\text { Chemical contaminants, including radioactivity } \\
\text { (Documentation on compliance with maximum } \\
\text { limits in the legislation) }\end{array}$ & & \\
\hline 10 & $\begin{array}{l}\text { Instructions of use } \\
\text { (If needed) }\end{array}$ & & \\
\hline 11 & Conclusion on the questionnaire & $\begin{array}{l}\text { (accepted/ } \\
\text { not accepted) }\end{array}$ & \\
\hline
\end{tabular}





\section{Guidance lists}

The names of the mushrooms in the Guidance lists are the preferred scientific names (common scientific synonyms in brackets).

When available, the preferred English name is given, whereas common English synonyms and trade names (with hyphens) are given in brackets. The nomenclature used is further explained in Volume II, section 2.

\section{List 1}

\section{Edible mushrooms suitable for commercial marketing (cultivated and/or wild)}

\section{1-01 Agaricus arvensi (Horse Mushroom)}

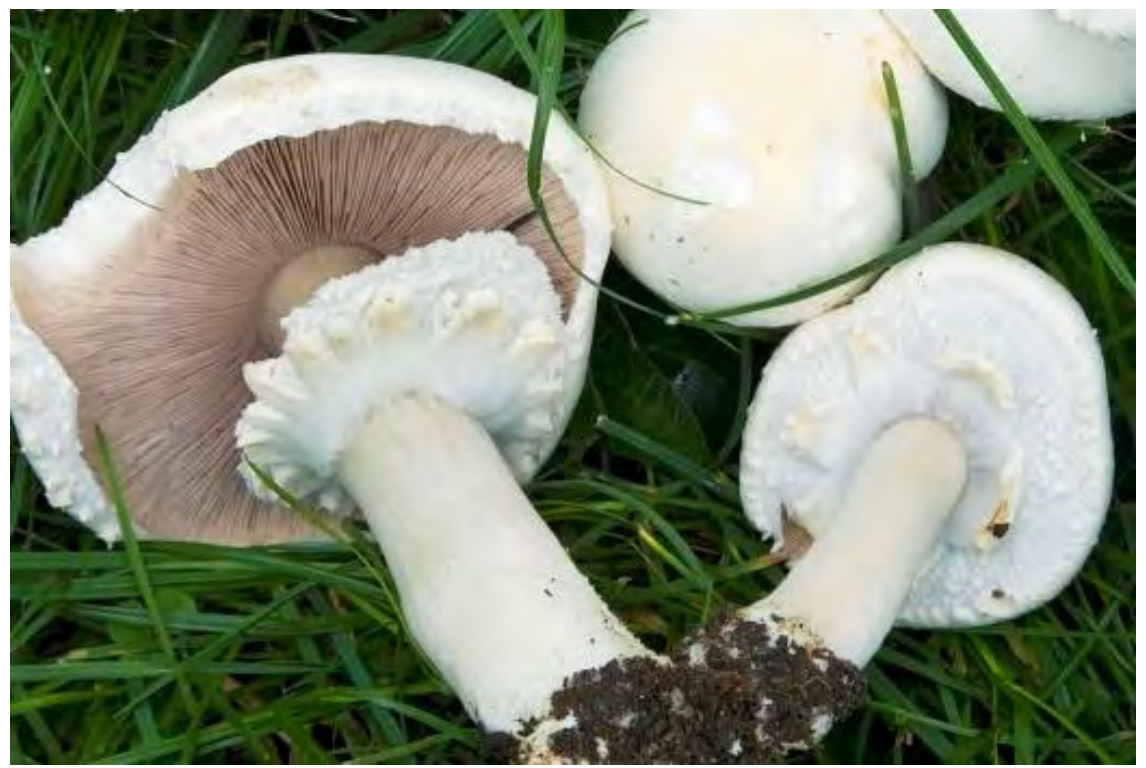

As Horse Mushroom efficiently bioaccumulates cadmium, the content of this toxic and carcinogenic metal should be regularly controlled

Due to the potentially high levels of phenylhydrazine derivatives and cadmium, Horse Mushroom should not be eaten in larger amounts (see A. bisporus (Button Mushroom) risk assessment).

The wild Horse Mushroom is in list 2. 
1-02 Agaricus bisporus (A. hortensis, A. brunnescens) (Cultivated Mushroom (Button Mushroom))

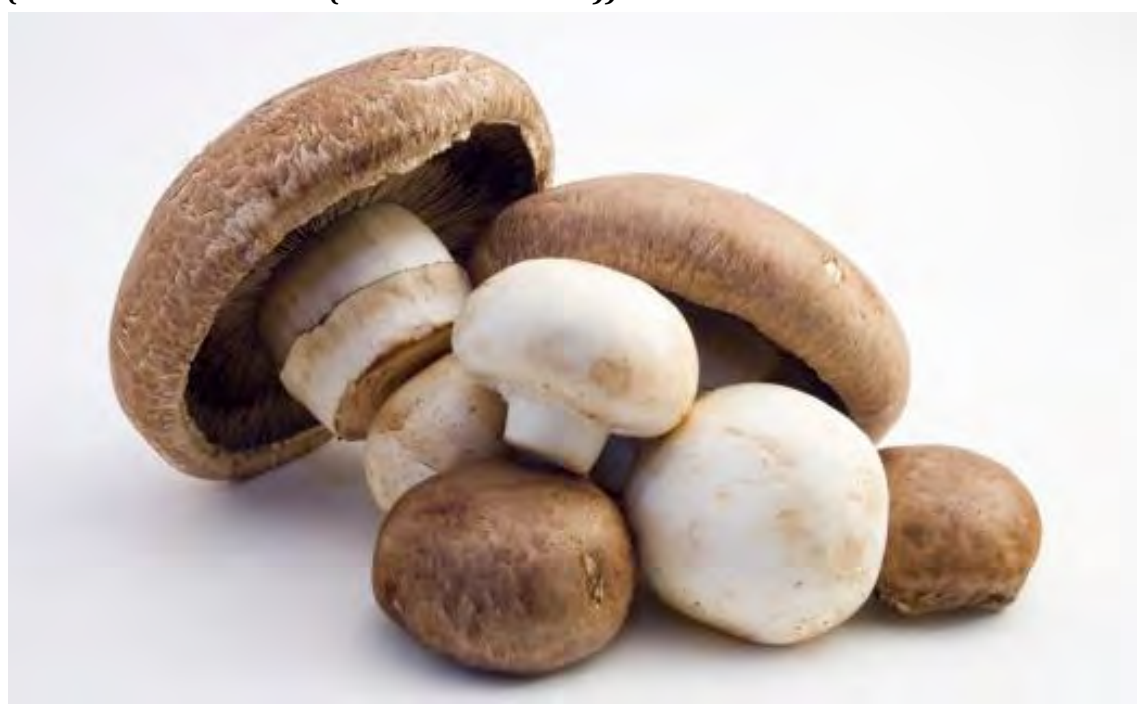

As it is concluded from animal and in vitro studies that the phenylhydrazine derivatives occuring in Button Mushroom (A. bisporus) as well as the mushroom itself may be genotoxic and carcinogenic, a carcinogenic risk for humans cannot be excluded.

It is therefore recommended not to eat Button Mushroom in larger amounts. A significantly higher intake than $2 \mathrm{~kg} /$ year (average consumption in Denmark, Iceland, Norway and Sweden) is regarded as "larger amounts". Proper processing of the fresh mushroom reduces the amounts of potentially carcinogenic constituents. The fried, microwave-heated, boiled (especially if boiling water is discarded), and canned mushrooms contain significantly less of the potentially carcinogenic phenylhydrazines. Also ordinary freezing and subsequent thawing (but not freeze-drying) will reduce the content of phenylhydrazine in the mushroom.

It is therefore recommended to process/cook Button Mushroom before consumption. 
1-03 Albatrellus ovinus (Forest Lamb)

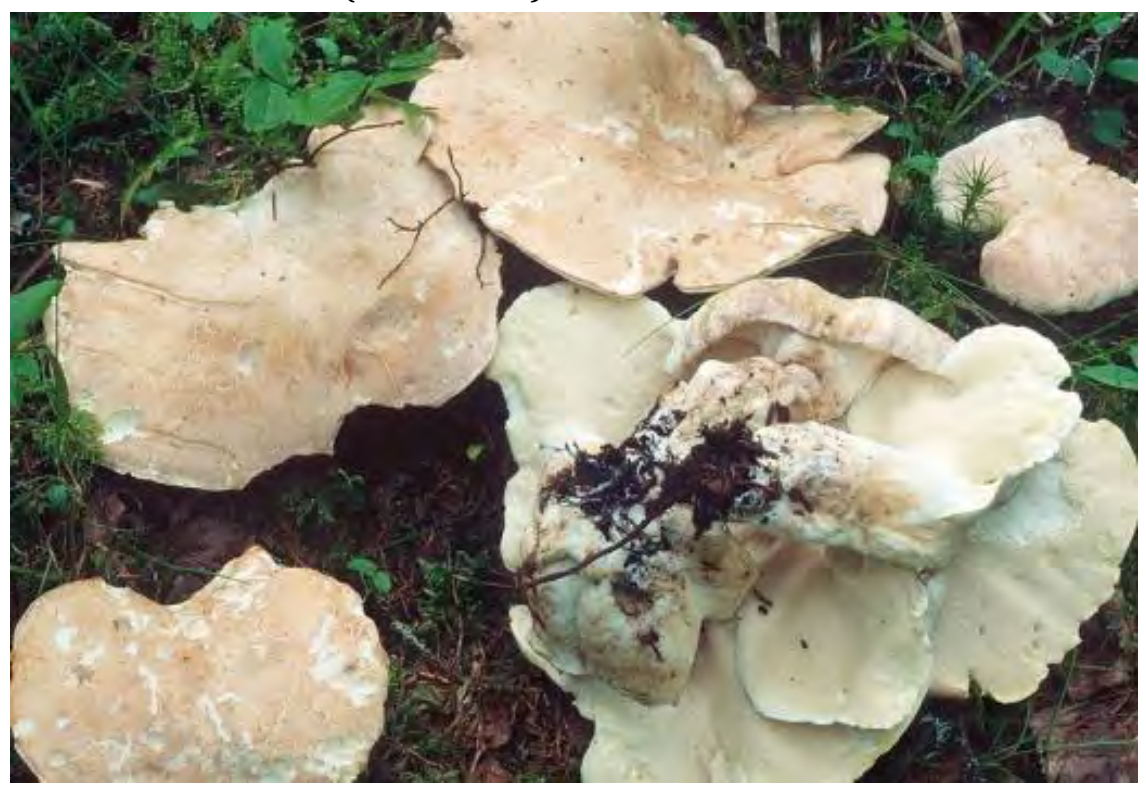

The mushroom is redlisted as regionally extinct in Denmark.

Should only be marketed in the Nordic countries, if it is from countries where it is cultivated or not red-listed

\section{1-04 Amanita caesarea (Caesar's Mushroom (Caesar's Amanita))}

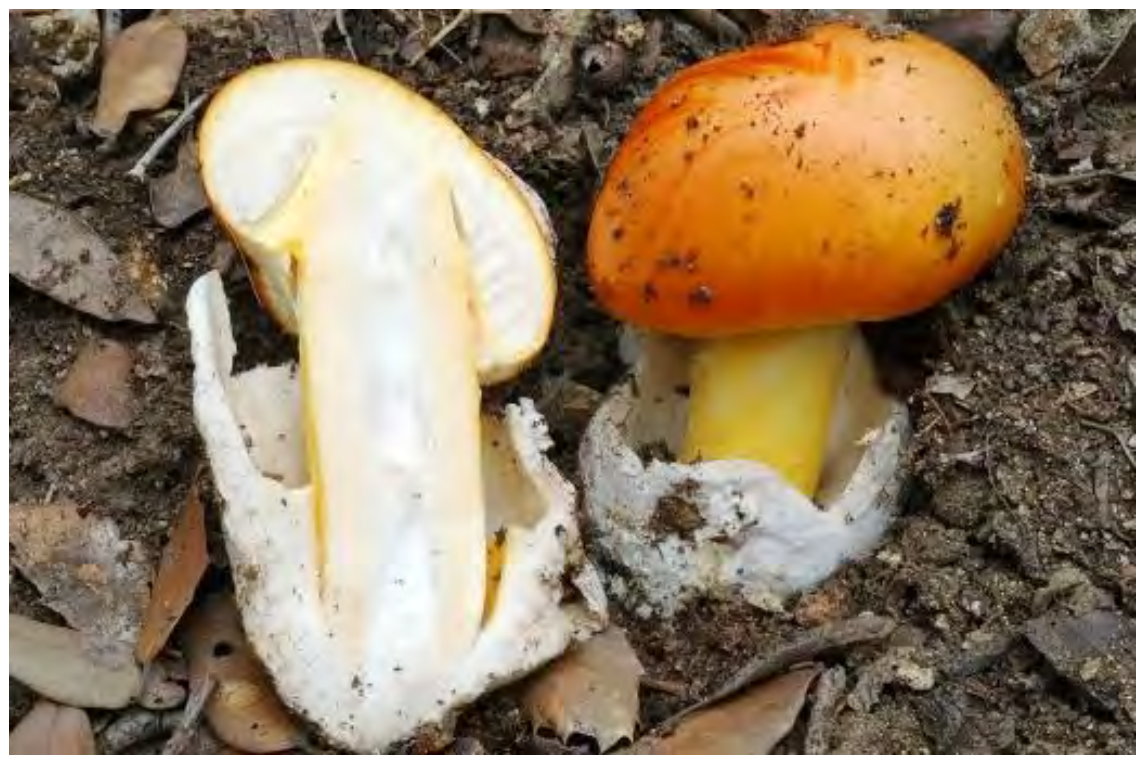


1-05 Auricularia auricula-judae. (A. auricula) (Jelly Ear(Jew's Ear, Judas's Ear Fungus))

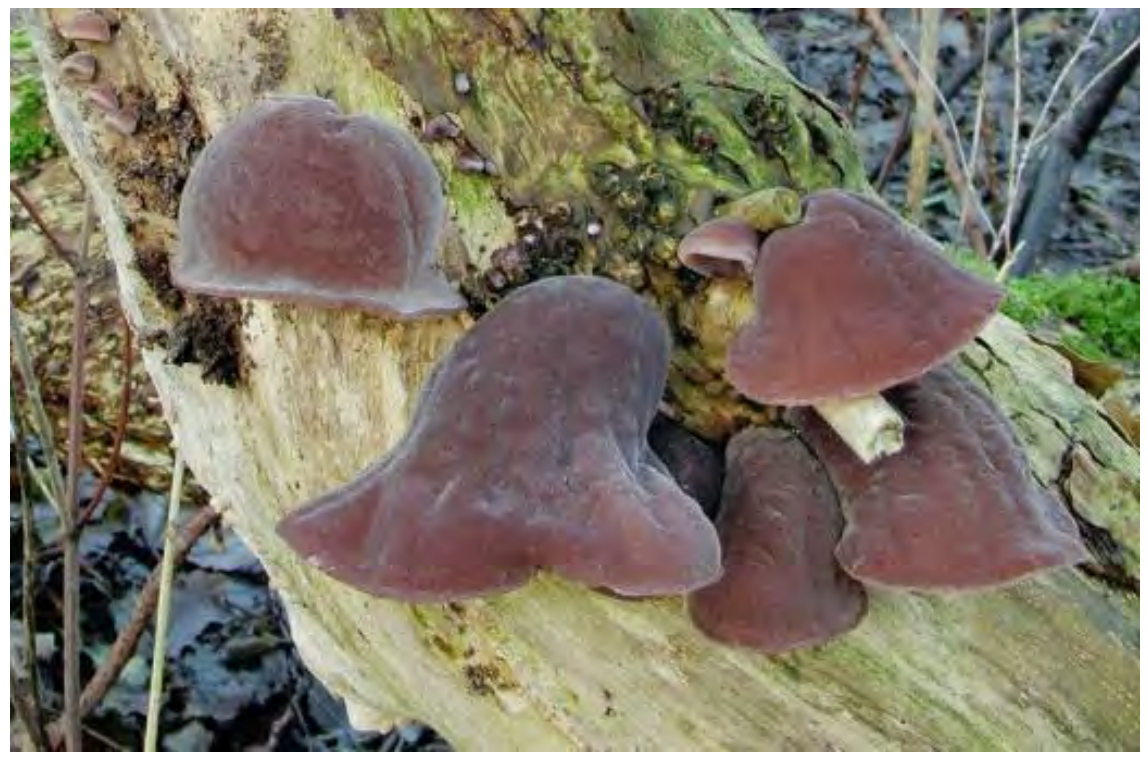

1-06 Auricularia cornea (A. polytricha) and other Auricularia species (Ear species)

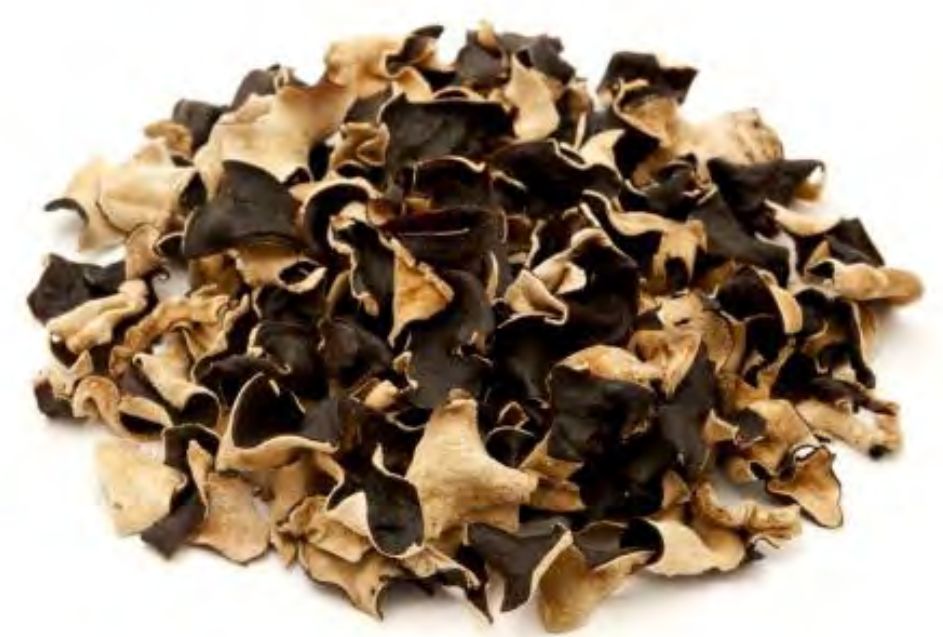


1-07 Boletus edulis (Penny Bun, Cep)

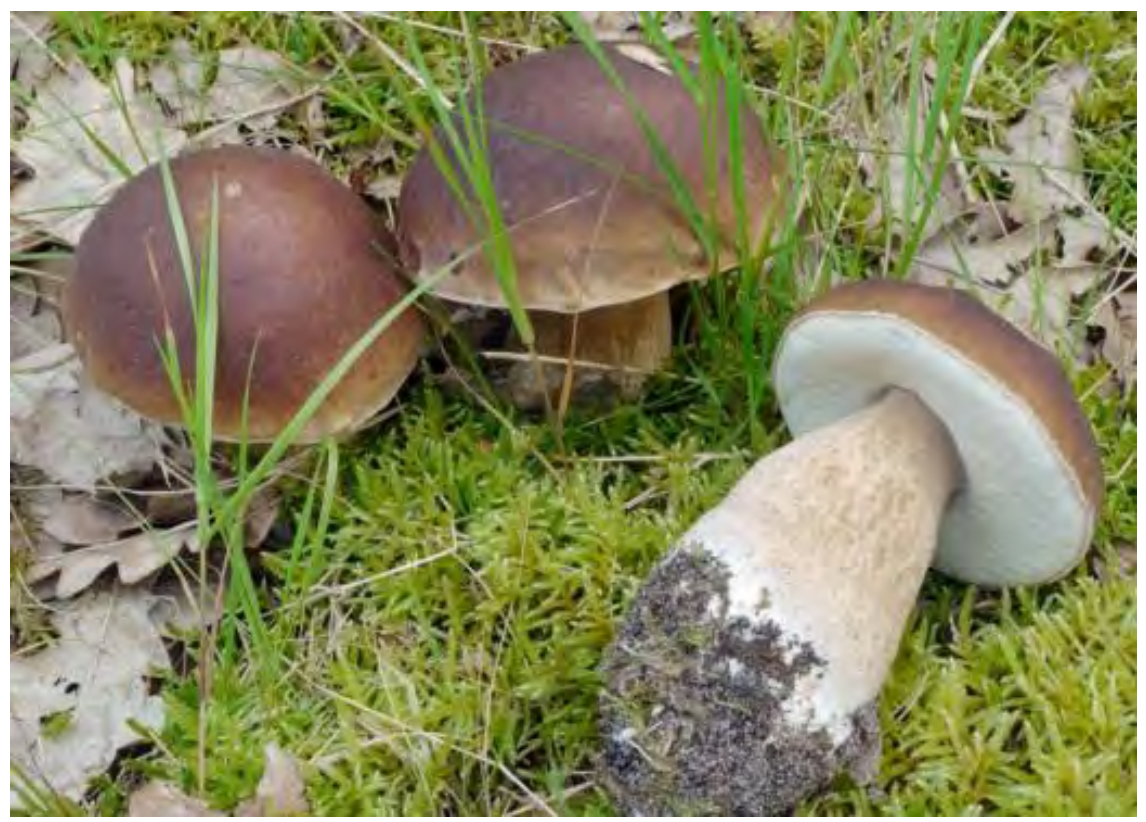

1-08 Boletus pinophilus (B. pinicola) (Pine Bolete("Pine Cep"))

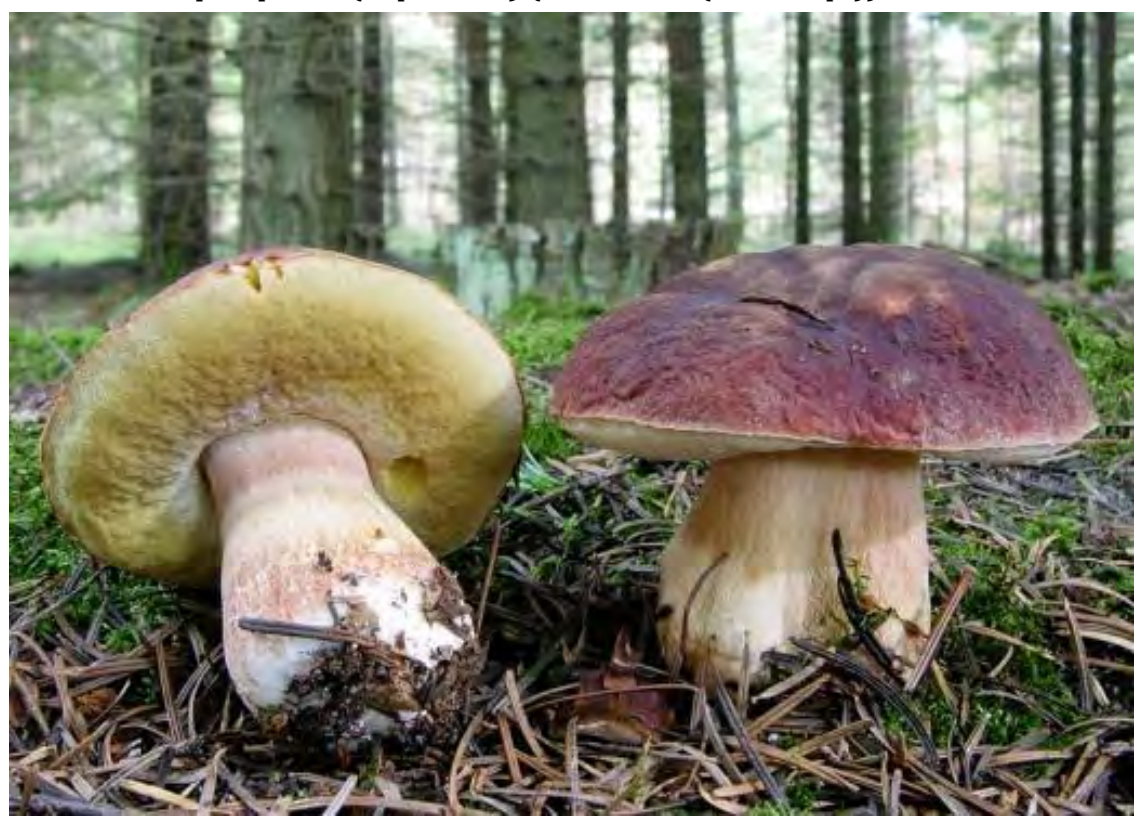


1-09 Boletus reticulatus (B. aestivalis) (Summer Bolete("Summer Cep"))

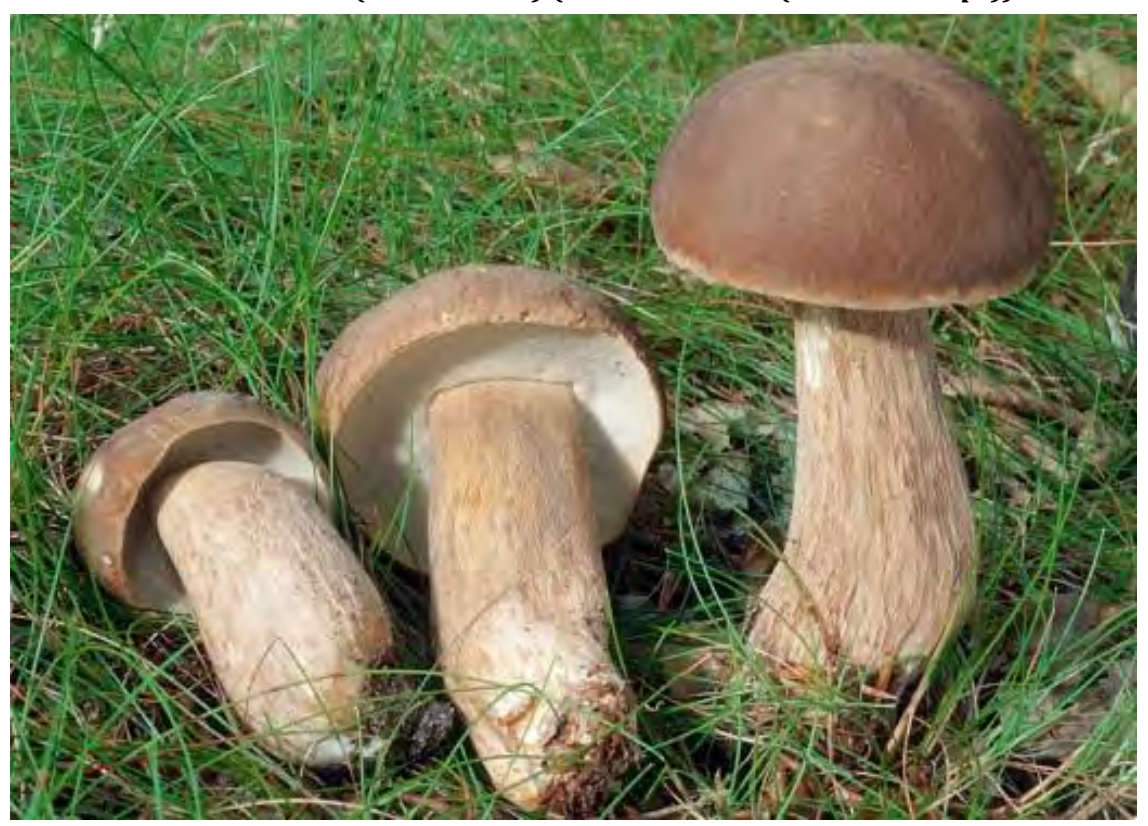

1-10 Cantharellus cibarius (Chanterelle ("Girolle"))

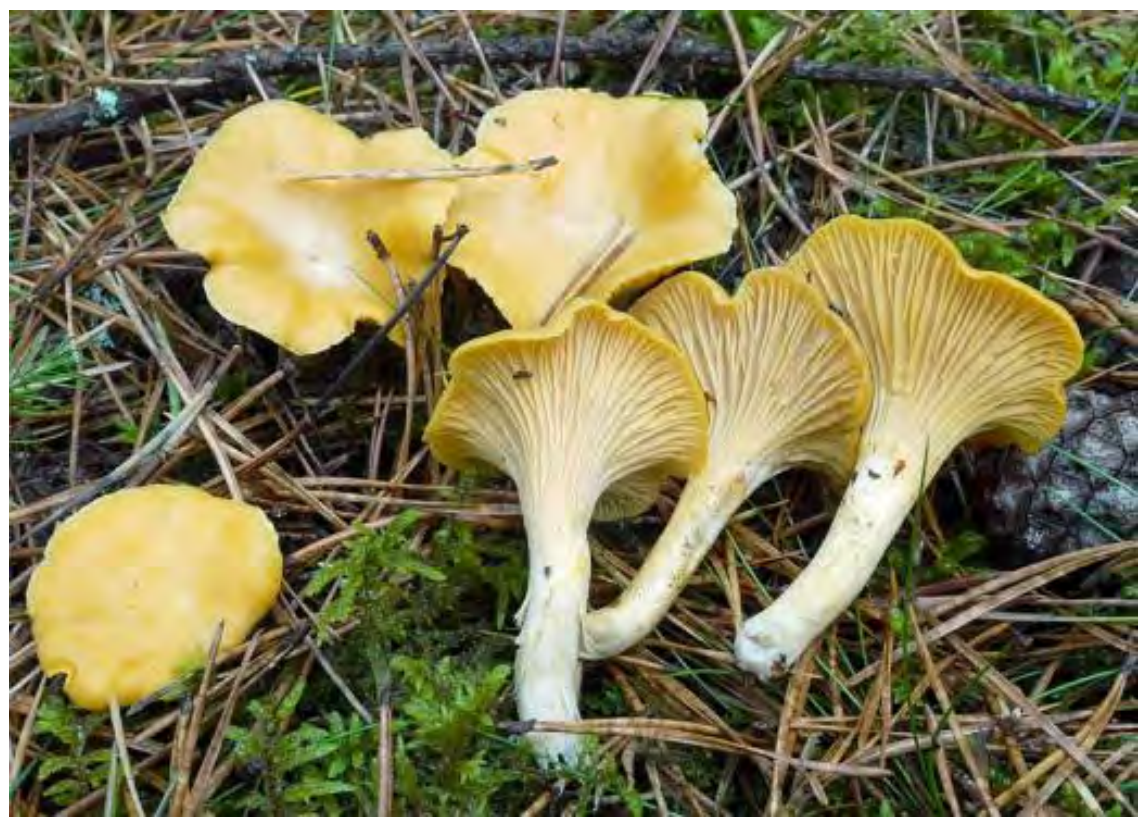


1-11 Cantharellus pallens (No English name)

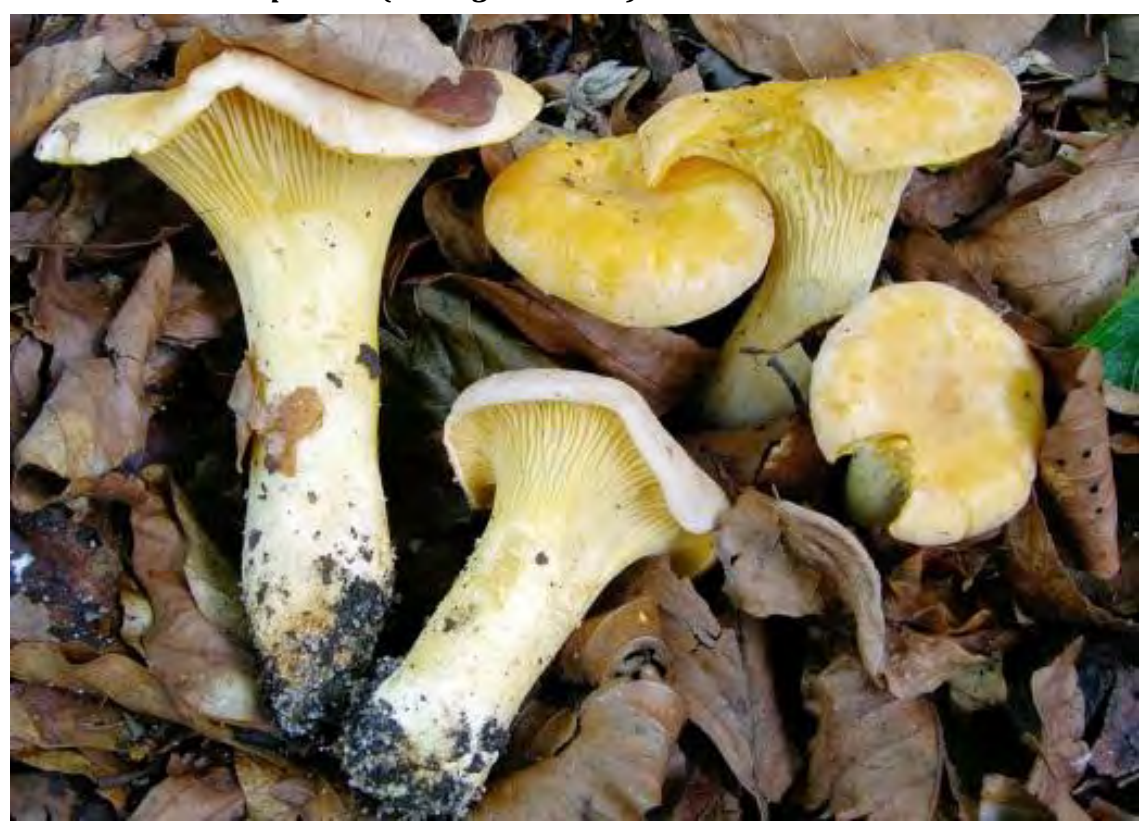

1-12 Craterellus cornucopioides (Cantharellus cornucopioides) (Horn of Plenty (Black Chanterelle, Black Trumpet))

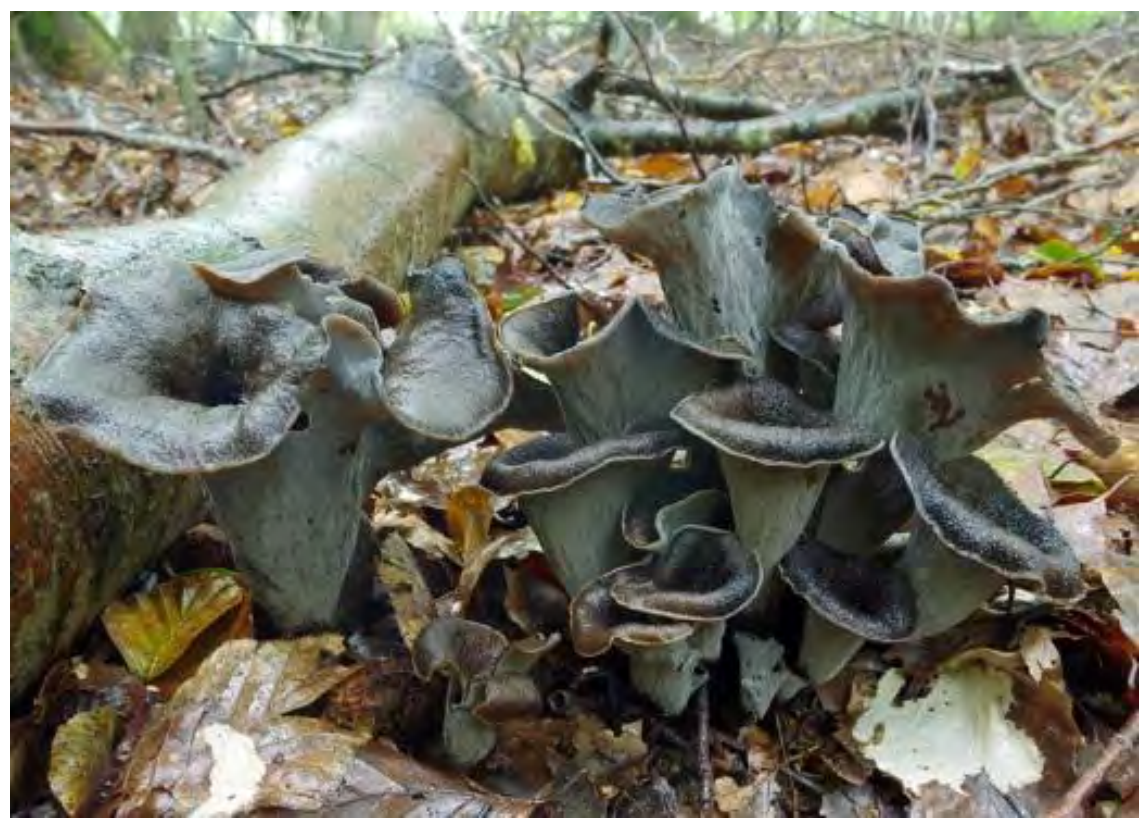


1-13 Craterellus lutescens (Cantharellus lutescens)

(Golden Chanterelle ("Chanterelle Jaune”, “Autumn Chanterelle"))

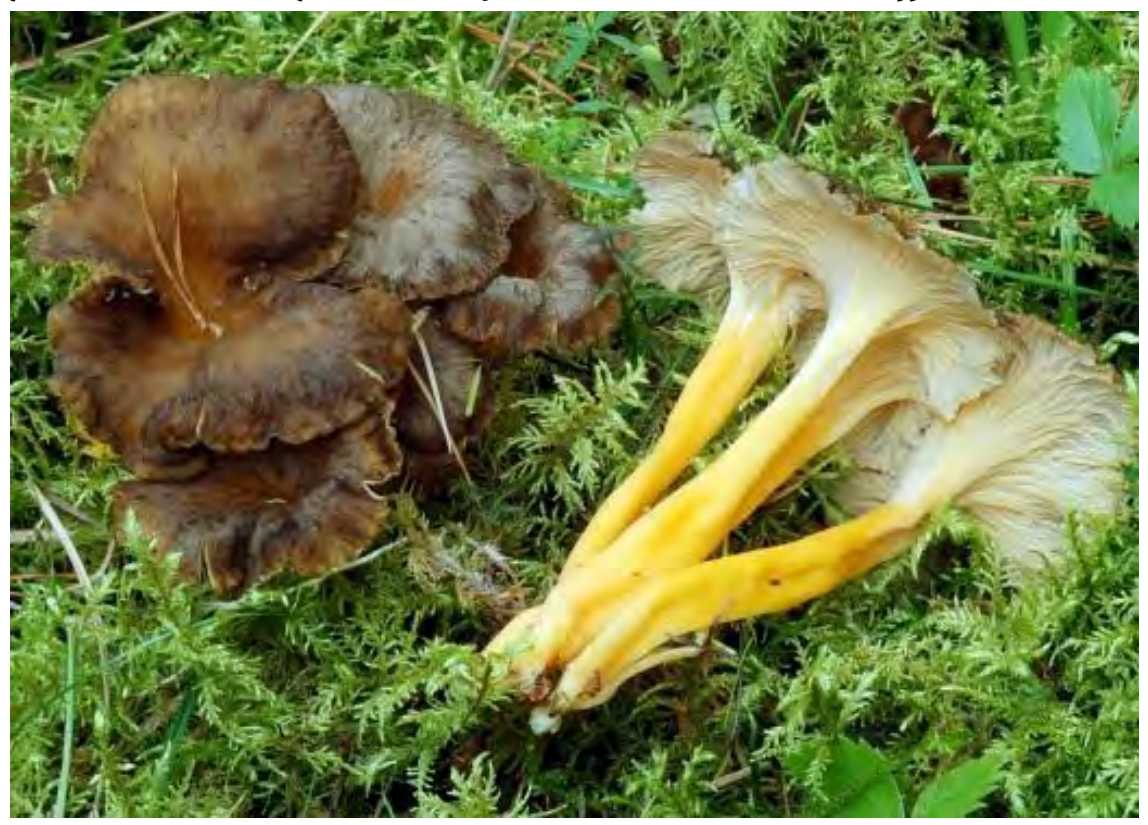

May form weak mutagenic compounds if injured.

1-14 Craterellus tubaeformis (Cantharellus tubaeformis)

(Trumpet Chantarelle ("Chanterelle gris",“Winter Chanterelle”))

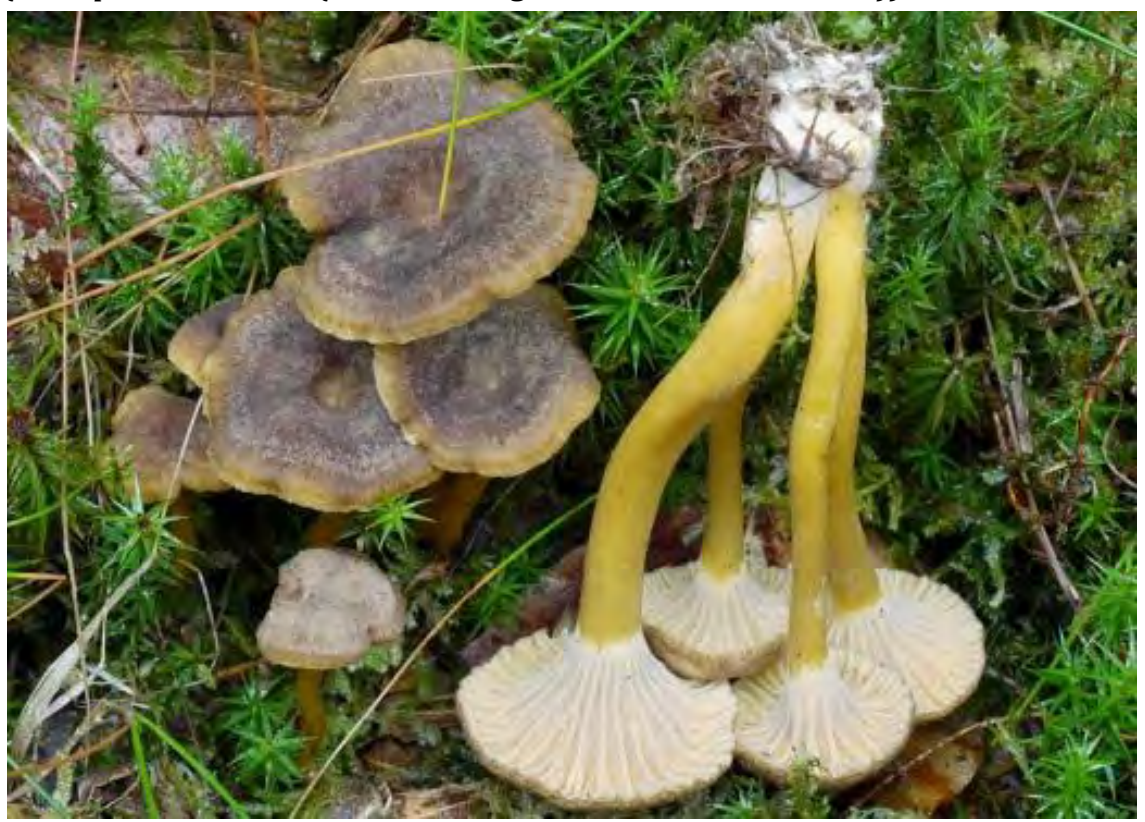

May form weak mutagenic compounds if injured. 
1-15 Flammulina velutipes (Velvet Shank ("Enoki-take”, “Golden Needle Mushroom”))

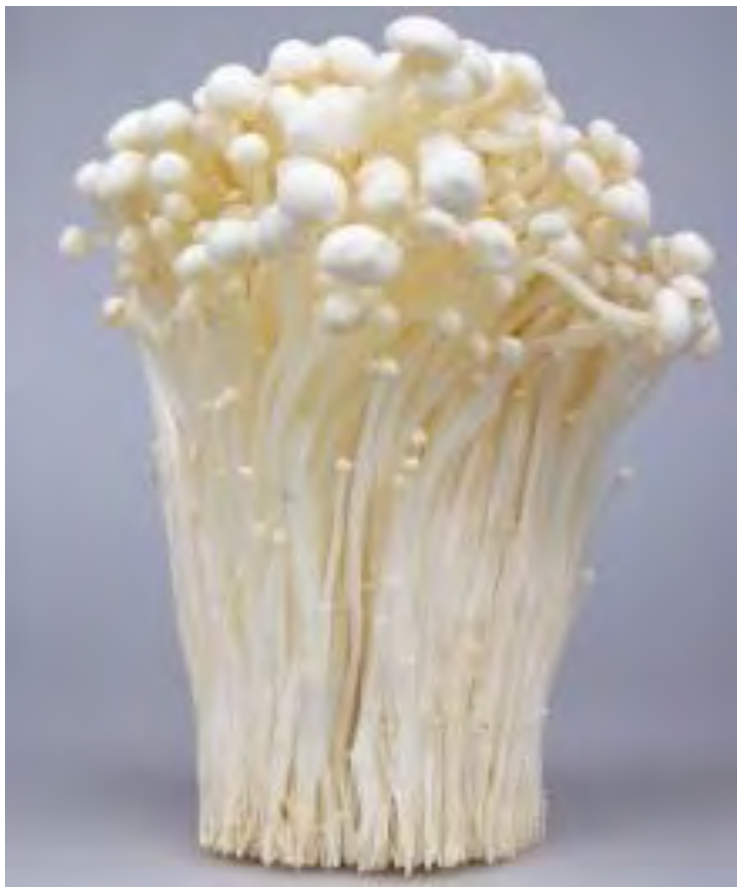

The wild Velvet Shank is in list 2.

\section{1-16 Grifola frondosa (Hen of the Woods)}

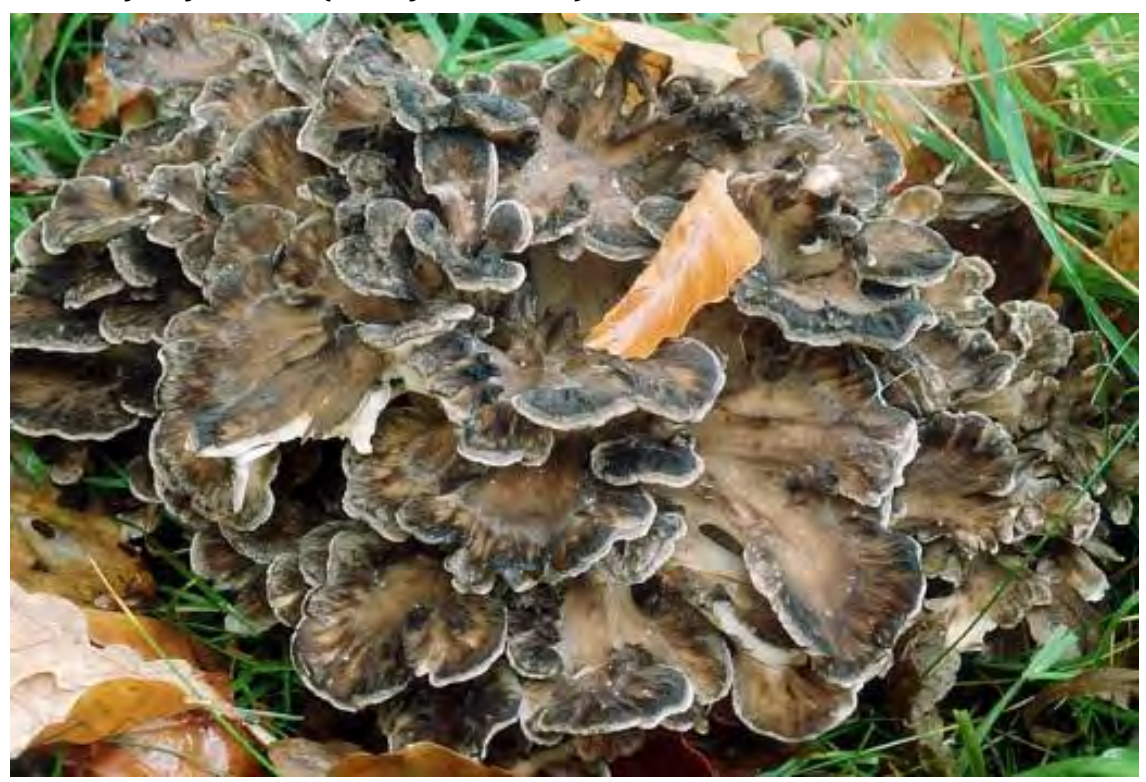

Red-listed in Denmark, Norway and Sweden as near threatened.

Should only be marketed in the Nordic countries, if it is from countries, where it is cultivated or not red-listed 


\section{1-17 Hericium coralloides (Coral Tooth)}

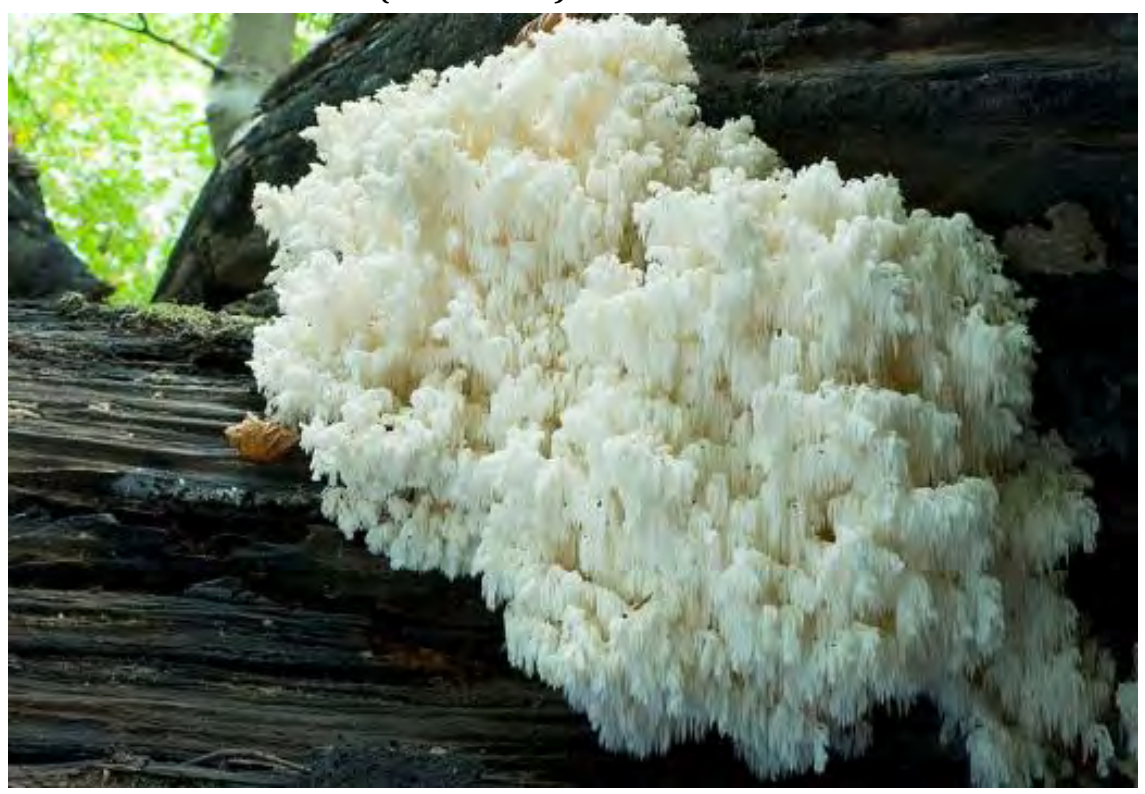

Red-listed in Denmark, Norway and Sweden as near threatened.

Should only be marketed in the Nordic countries, if it is from countries, where it is cultivated or not red-listed

\section{1-18 Hericium erinaceus (Bearded Tooth)}

(“Lion's Mane”, “Mushroom”,“Pom Pom”)

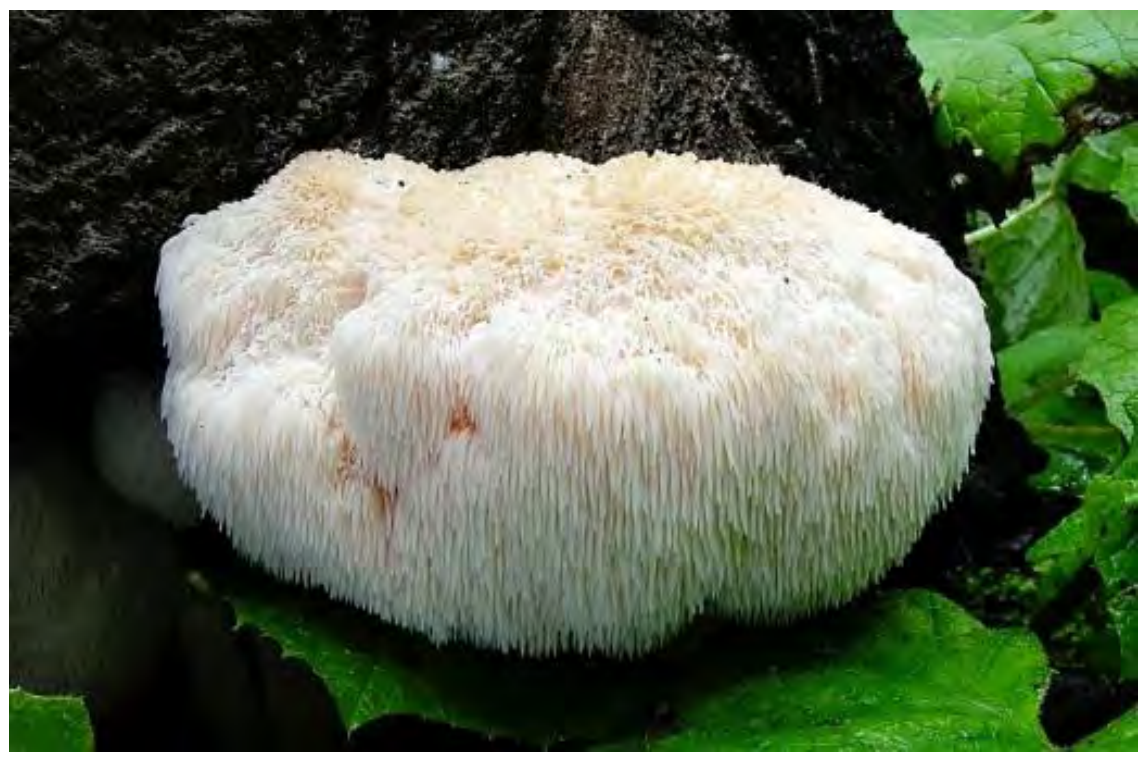

Redlisted in Denmark, Sweden and Norway as critically endangered.

Should only be marketed in the Nordic countries, if it is from countries where it is cultivated or not red-listed. 
1-19 Hydnum repandum (Wood Hedgehog)

("Pied de Mouton", “Hedgehog")

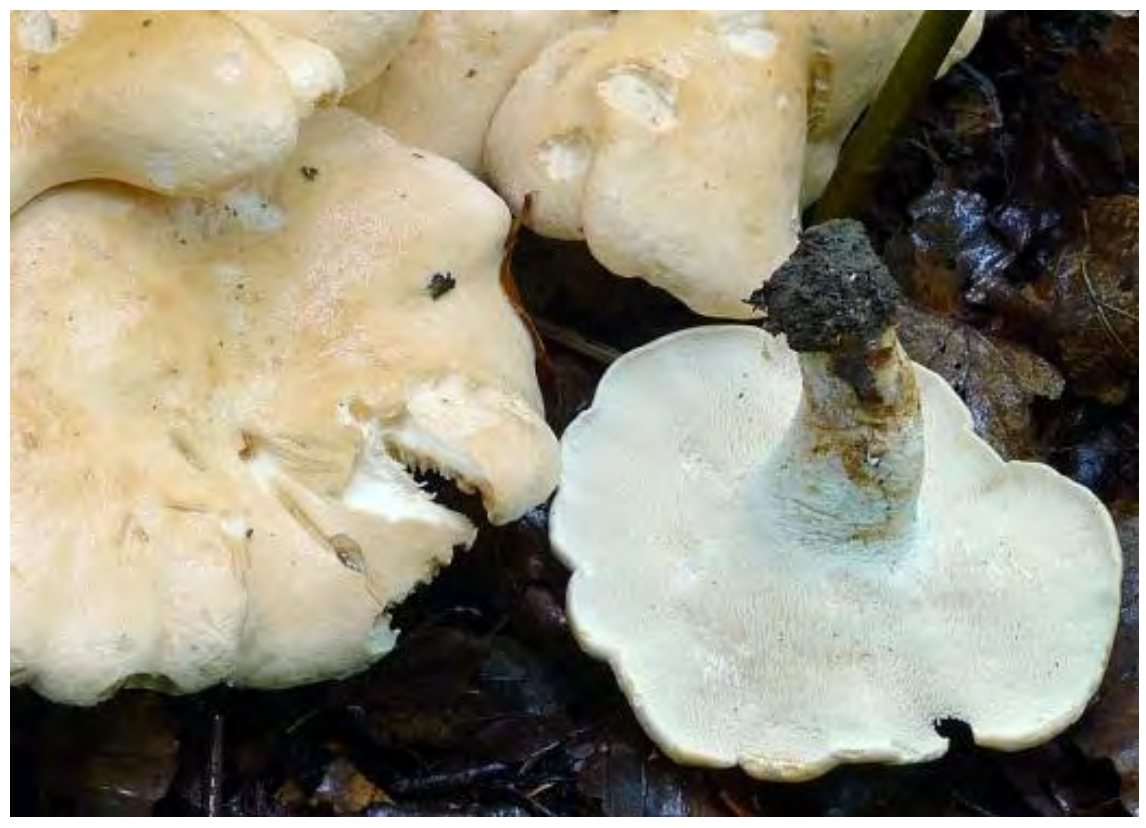

\section{1-20 Hydnum rufescens (Terracotta Hedgehog)}

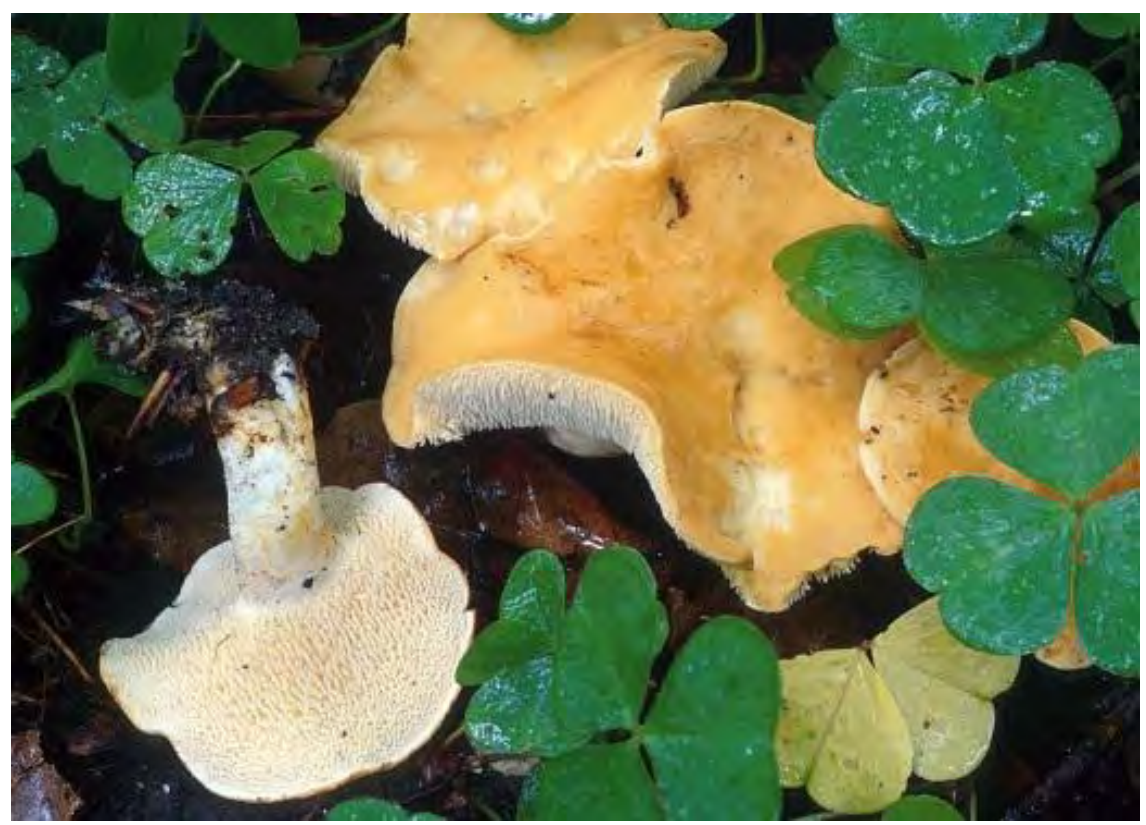


1-21 Hypsizygus spp (Elm Leech) (Brown Beech Mushroom, White Beech Mushroom("Brown Shimeji”, “White Shimeji”))

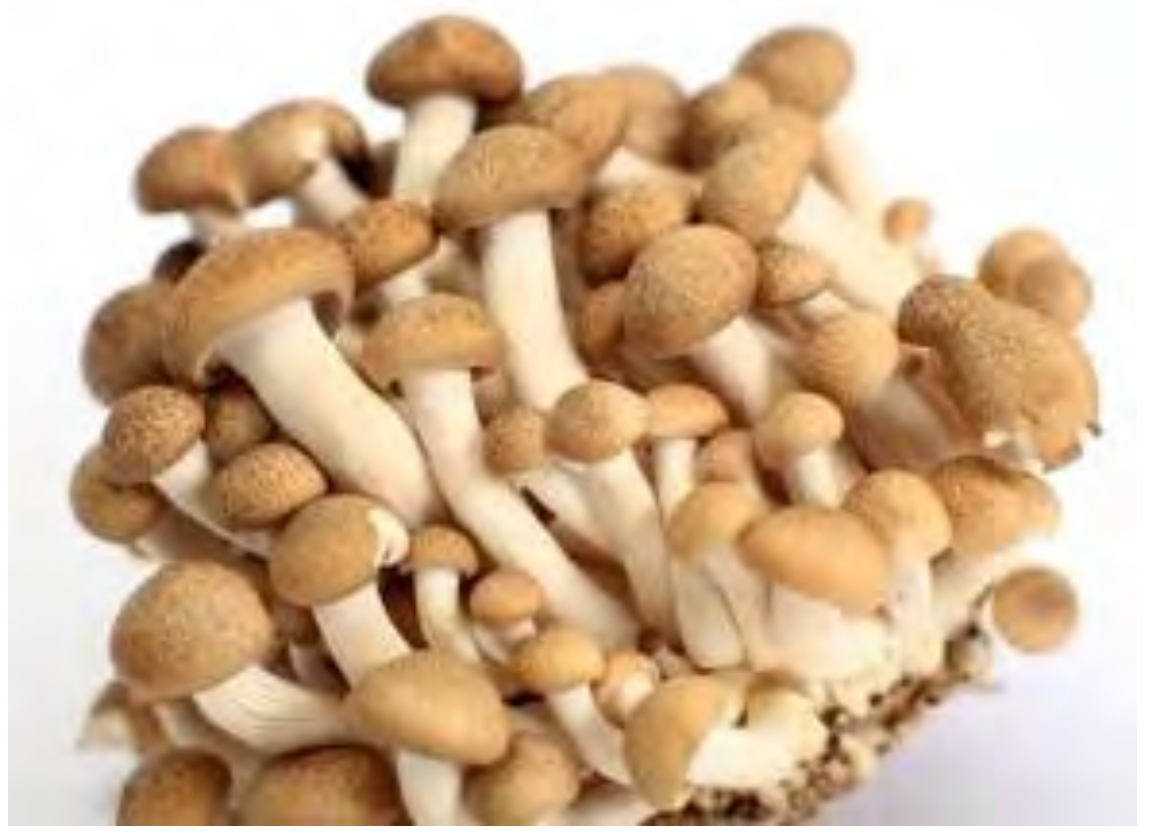

\section{1-22 Lentinula edodes (Lentinus edodes) (Shii-take)}

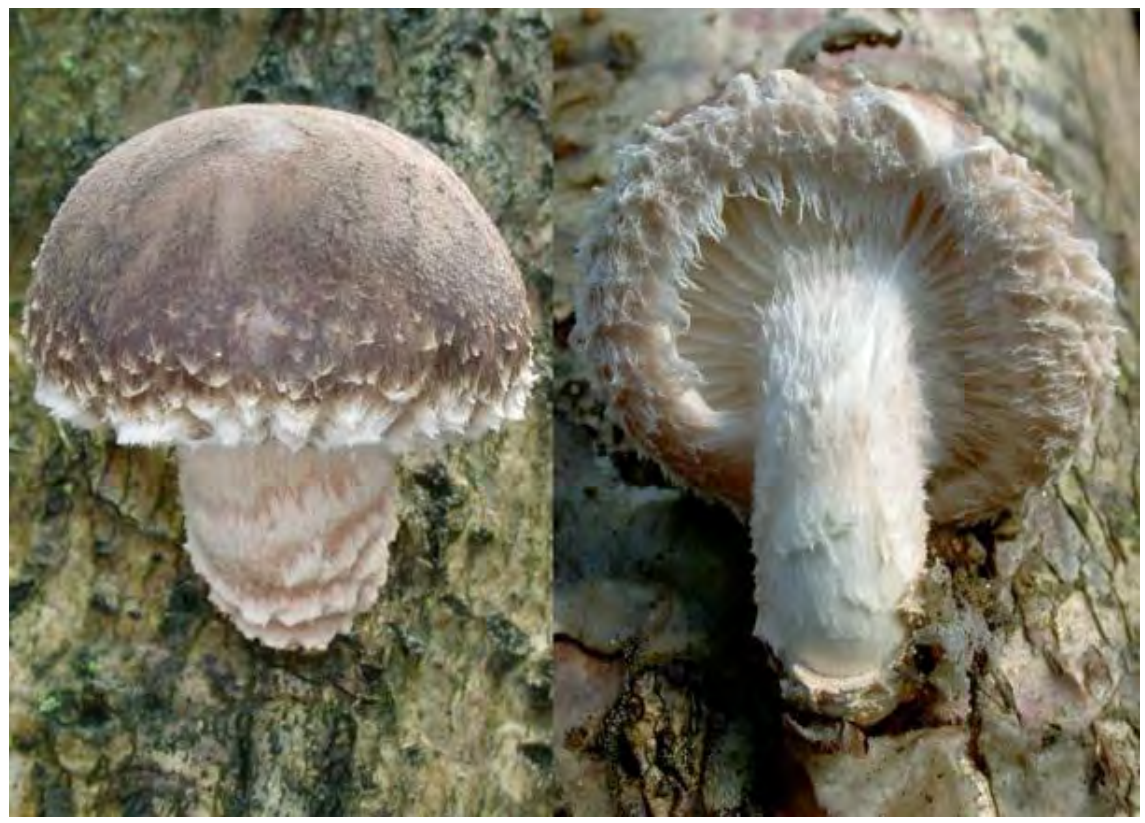


1-23 Lepista nuda (Tricholoma nudum)( Wood Blewit)

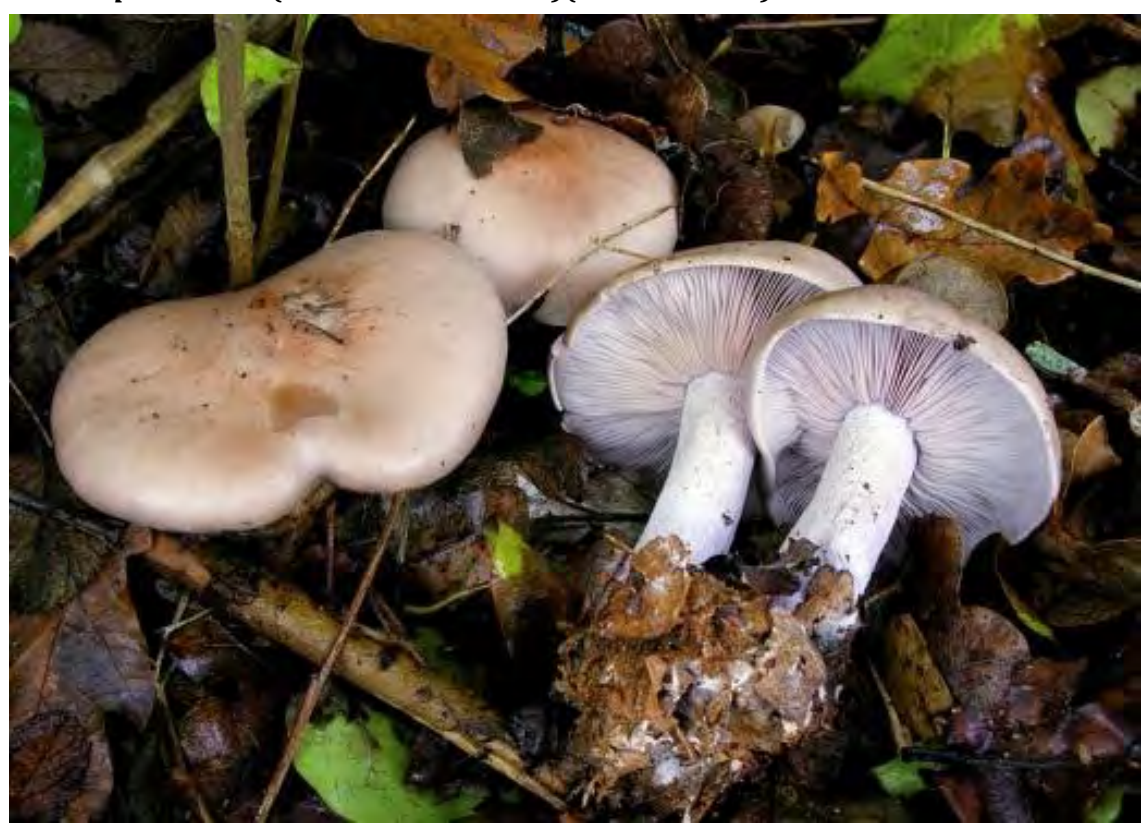

The wild Wood Blewit is in list 2.

\section{1-24 Macrolepiota procera (Parasol)}

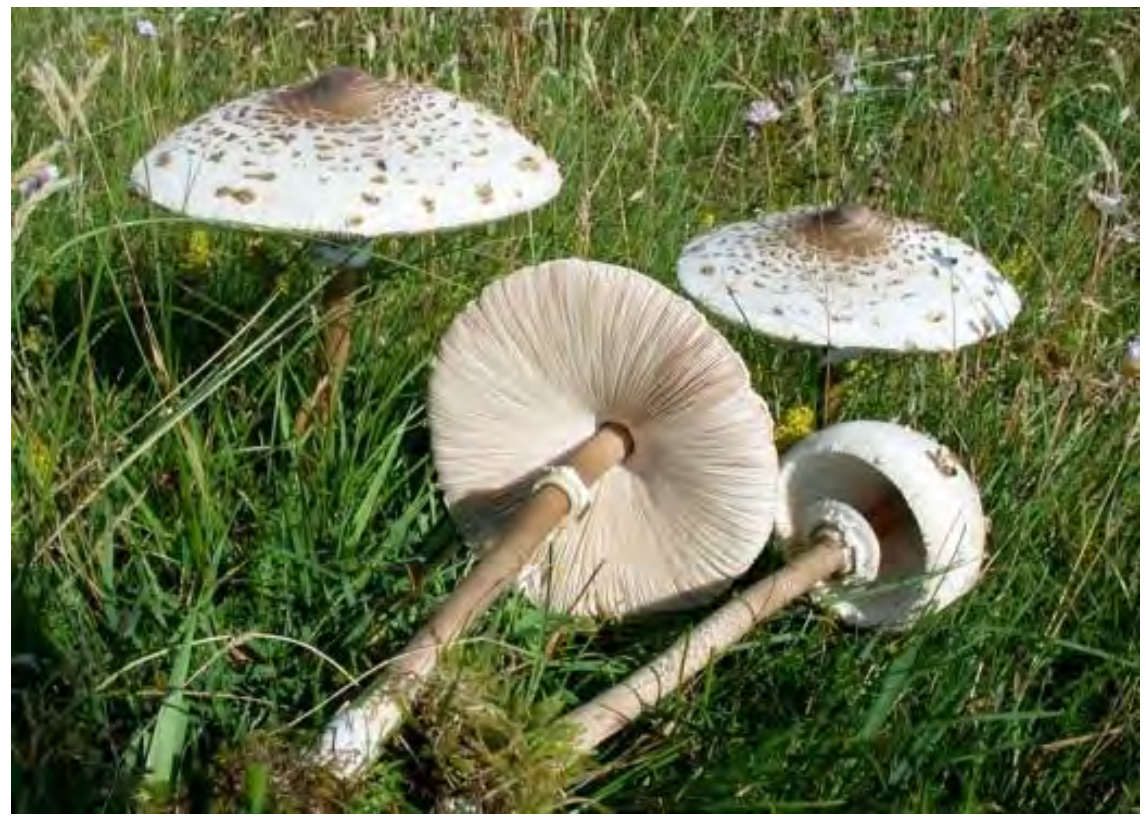


1-25 Morchella conica. (M. elata)( Black Morel ("Morel”, "Pointed Morel”, “Ribbed Morel"))

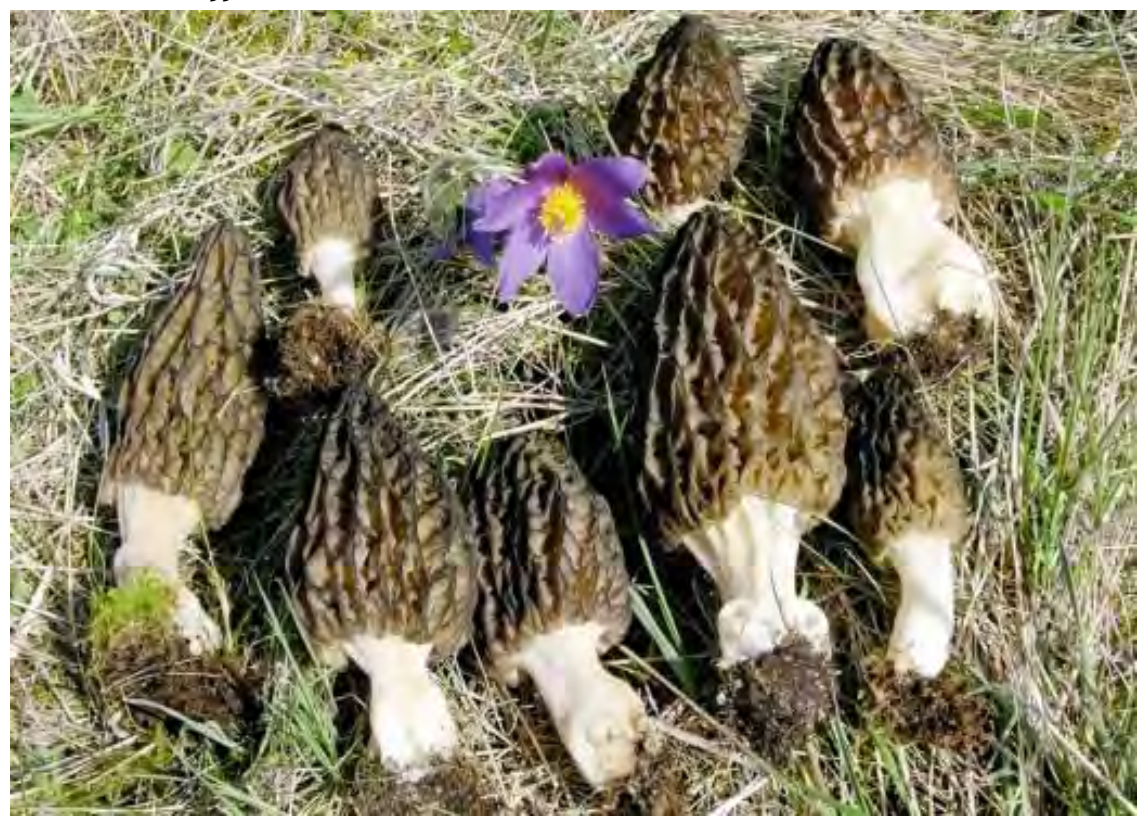

Black Morel (M. conica and the closely related Morel (M. esculenta): Should never be eaten raw and should be cooked for at least 10 minutes

Intake of higher amount (more than $100 \mathrm{~g}$ per meal) of cooked, fresh - or corresponding amounts of dried morels - may occasionally, beyond gastro-intestinal disturbances, give rise to neurological effects like ataxia, dizziness and visual disturbances and should accordingly be avoided. 


\section{1-26 Morchella esculenta (Morel)}

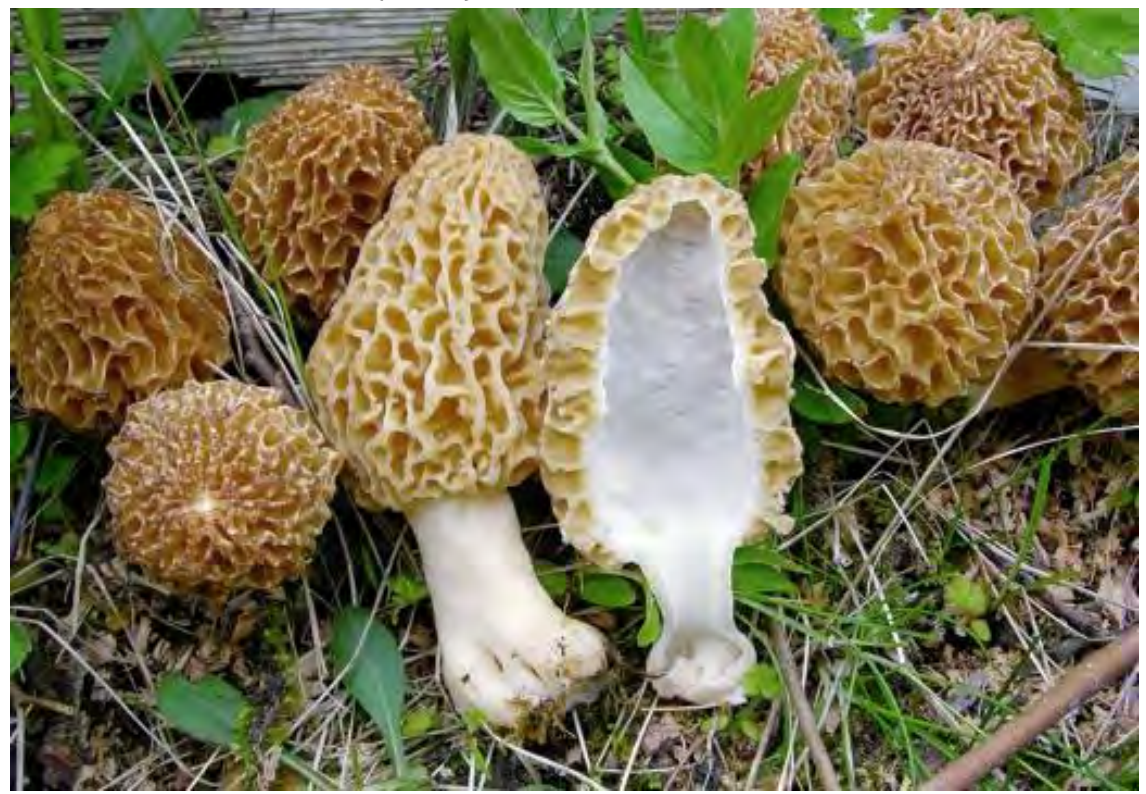

Morel (M. esculenta) and the closely related Black Morel ( $M$. conica): Should never be eaten raw and should be cooked for at least 10 minutes.

Intake of higher amounts (more than $100 \mathrm{~g}$ per meal) of cooked, fresh - or corresponding amounts of dried morel - may occasionally, beyond gastro-intestinal disturbances, give rise to neurological effects like ataxia, dizziness and visual disturbances and should accordingly be avoided.

\section{1-27 Pholiota nameko ("Pholiote”, “Nameko")}

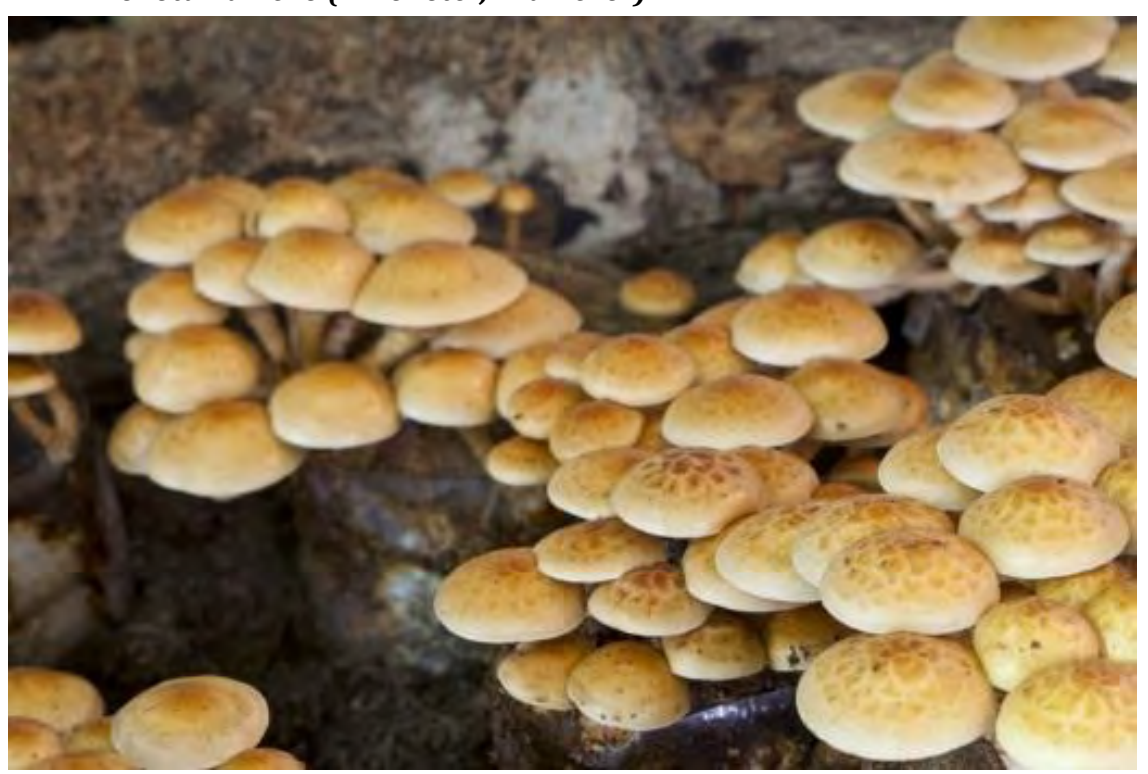


1-28 Pleurotus citrinopileatus (The Golden Oyster Mushroom)

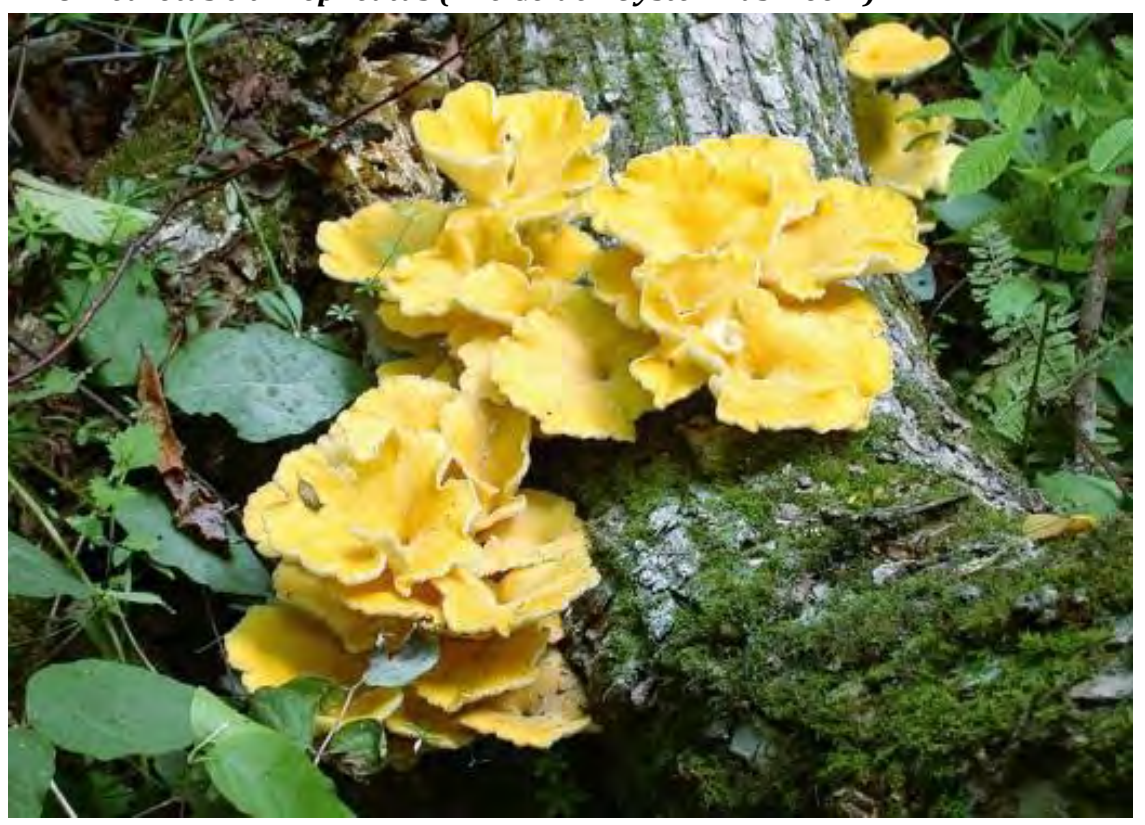

\section{1-29 Pleurotus djamor (Pink Oyster Mushroom)}

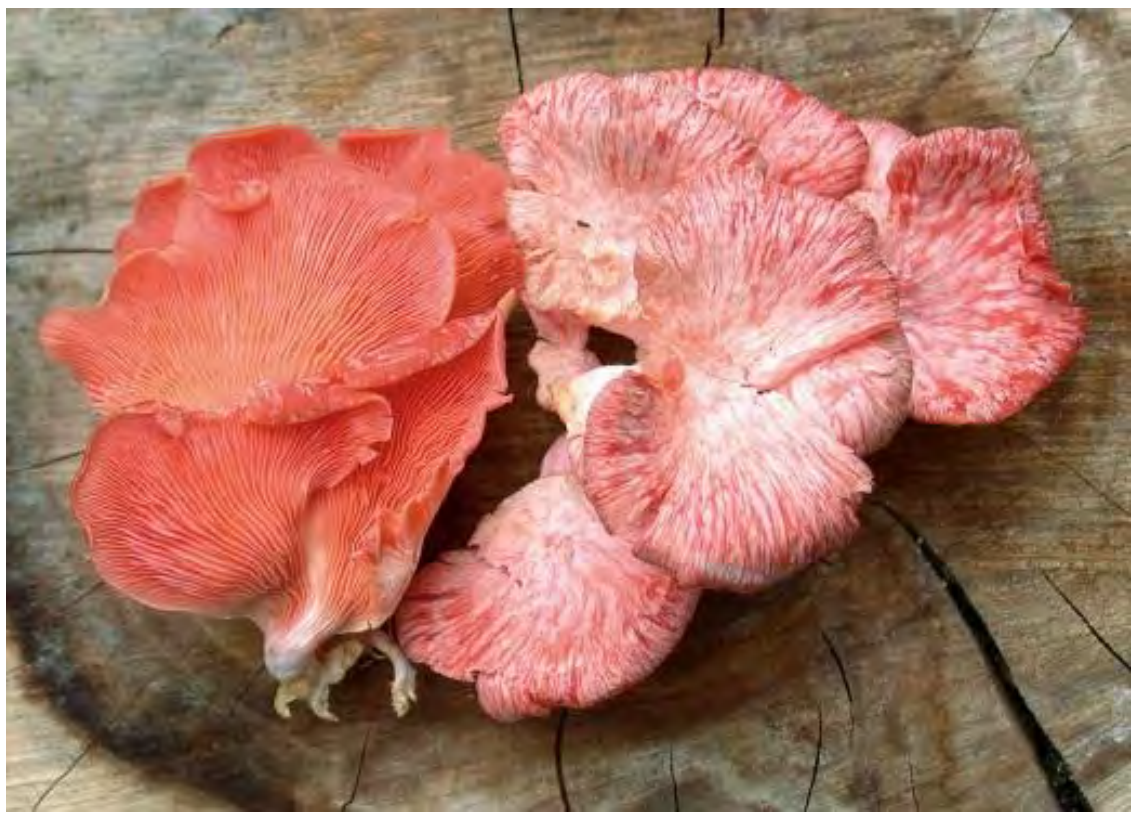


1-30 Pleurotus eryngii (French Horn Mushroom, King Trumpet Mushroom (“King Oyster"))

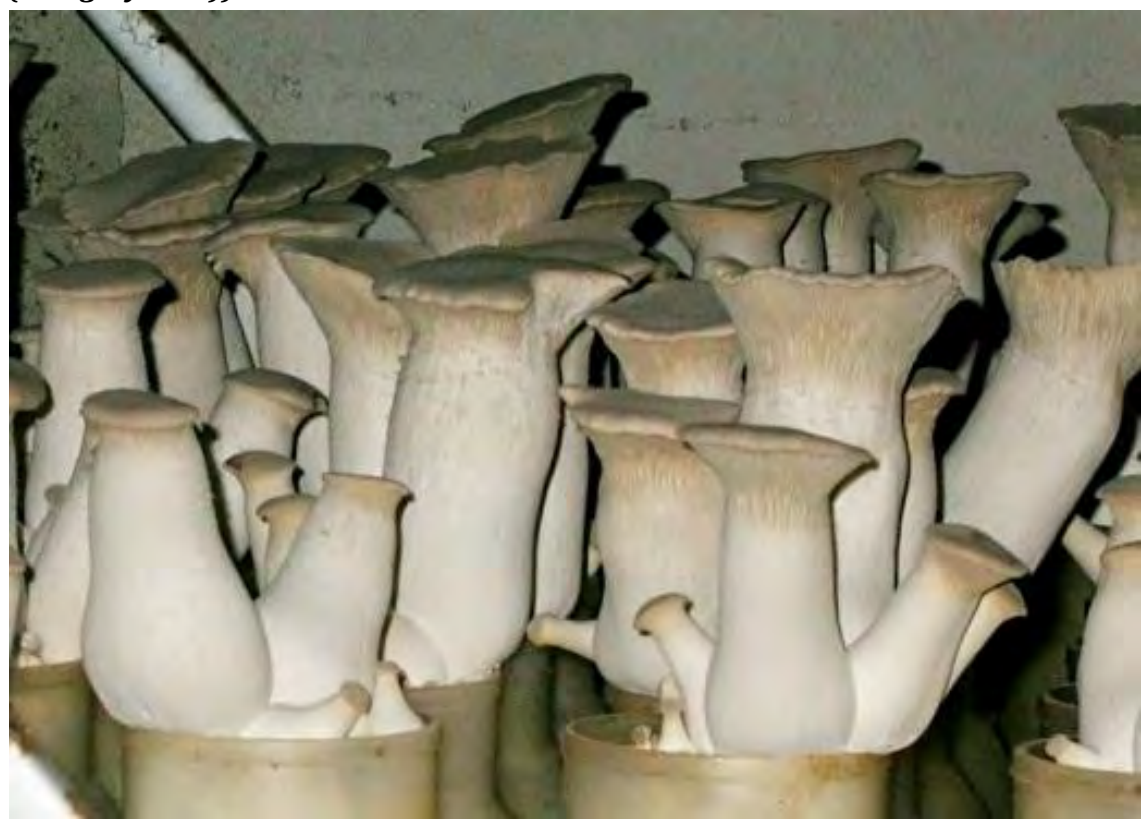

\section{1-31 Pleurotus ostreatus (Oyster Mushroom)}

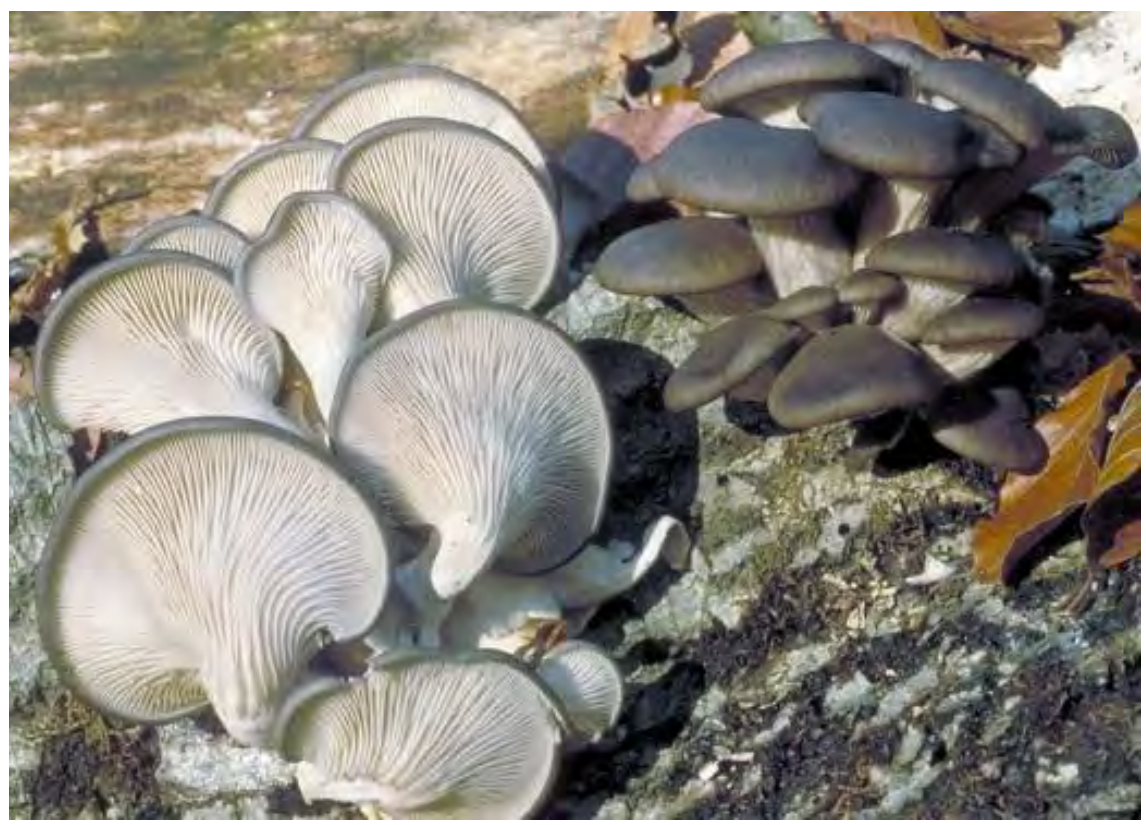


1-32 Sparassis crispa (Wood Cauliflower)

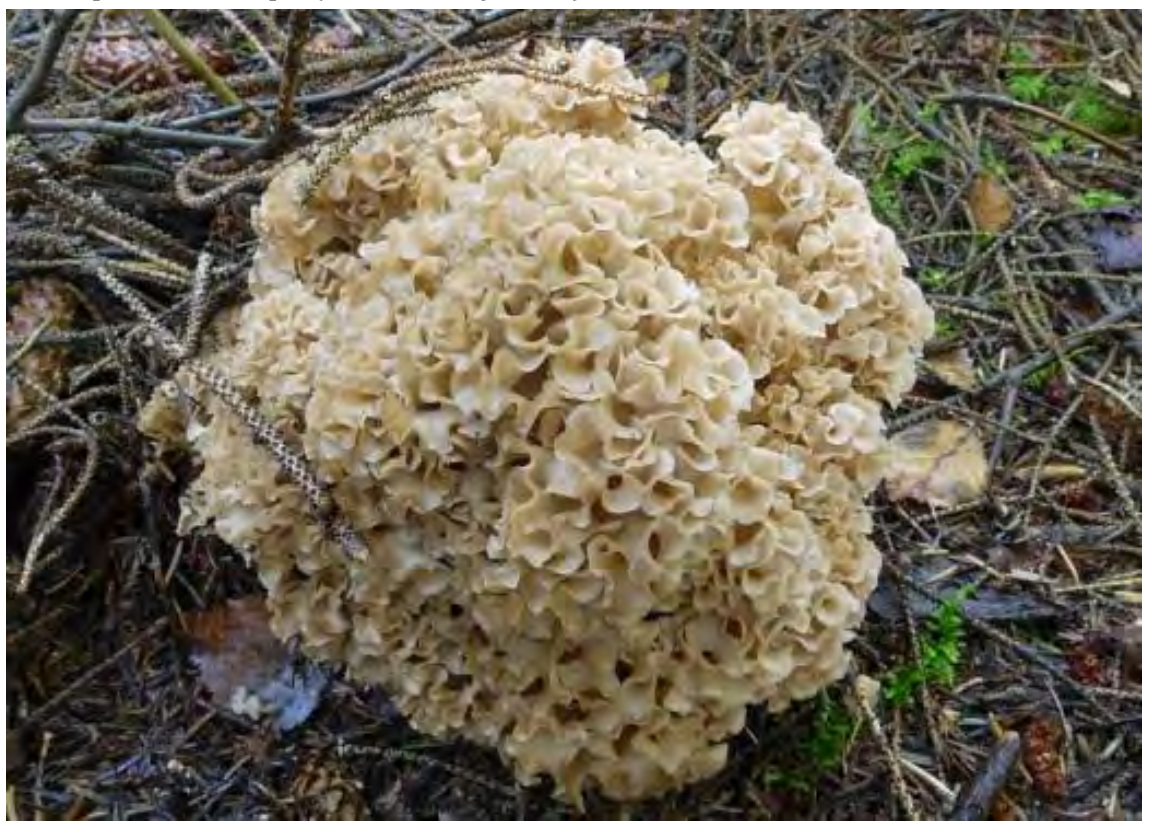

\section{1-33 Suillus luteus (Slippery Jack)}

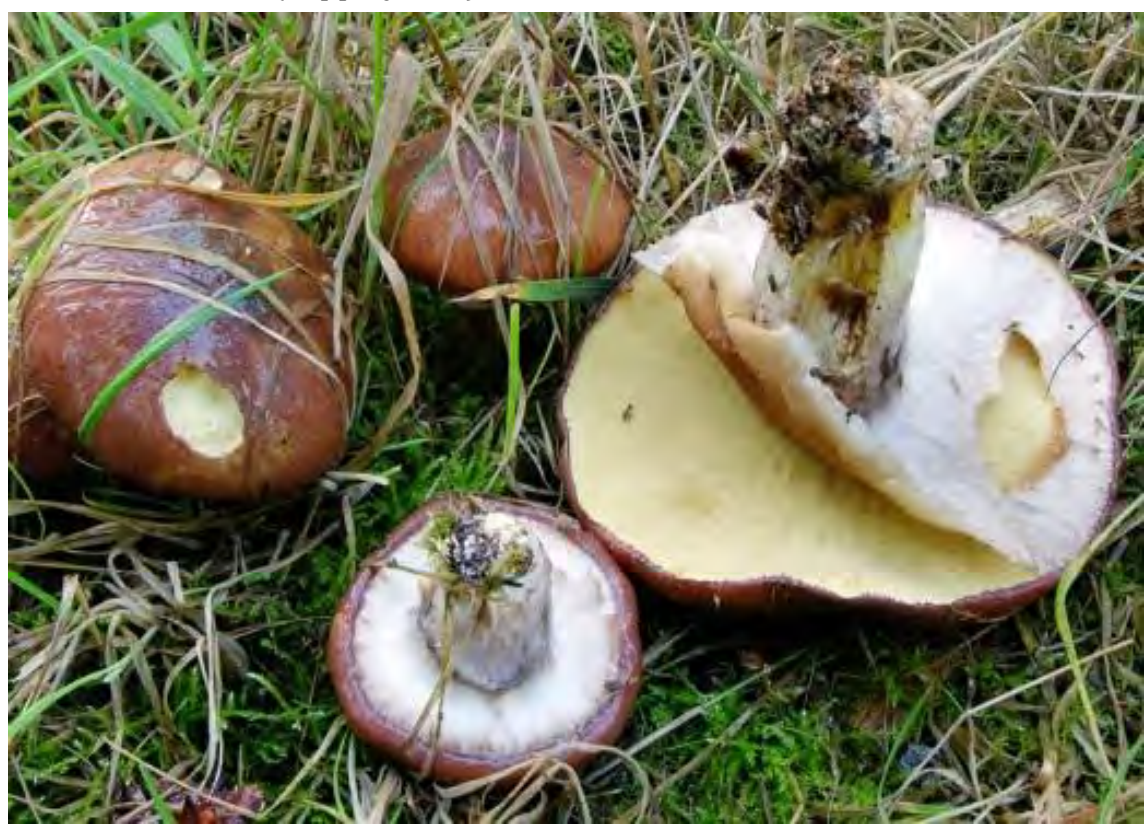


1-34 Tricholoma matsutake (T. nauseosum) (Spicy Knight(“Matsu-take"))

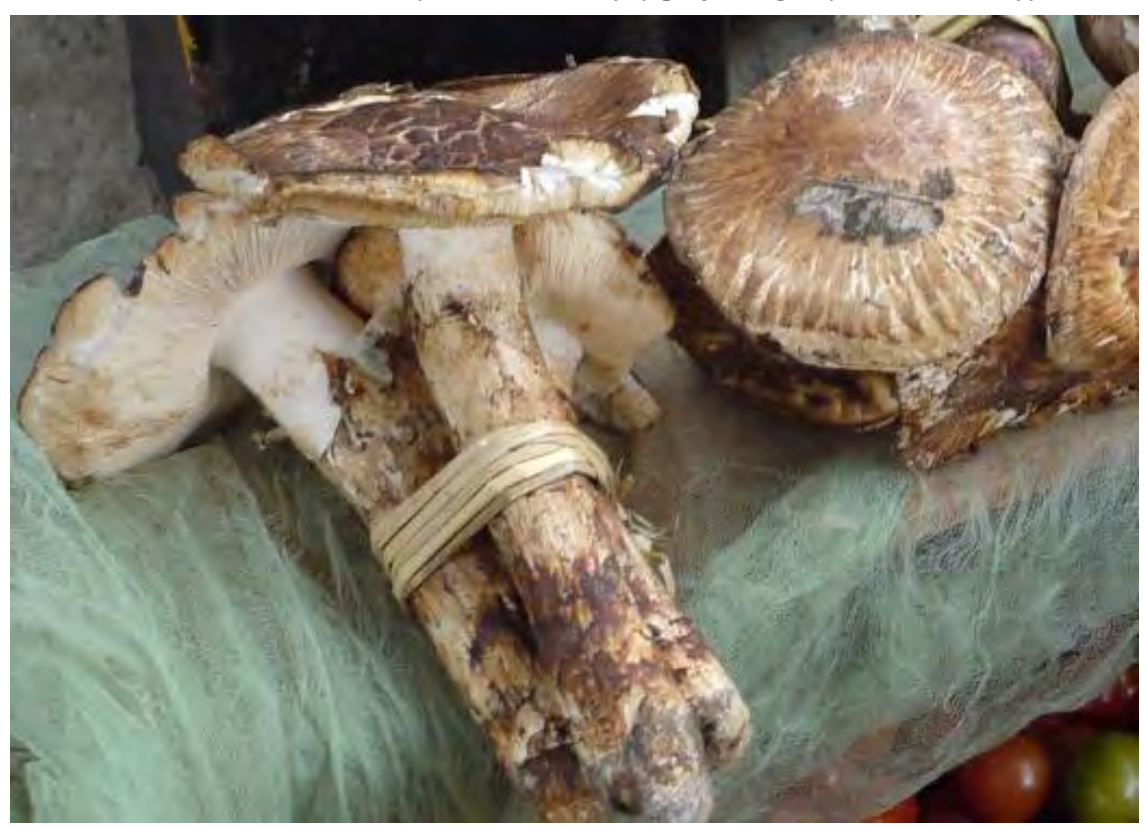

Is red-listed in Denmark and Norway as near threatened.

Should only be marketed in the Nordic countries, if it is from countries, where it is not red-listed.

\section{1-35 Tuber aestivum (Summer Truffle)}

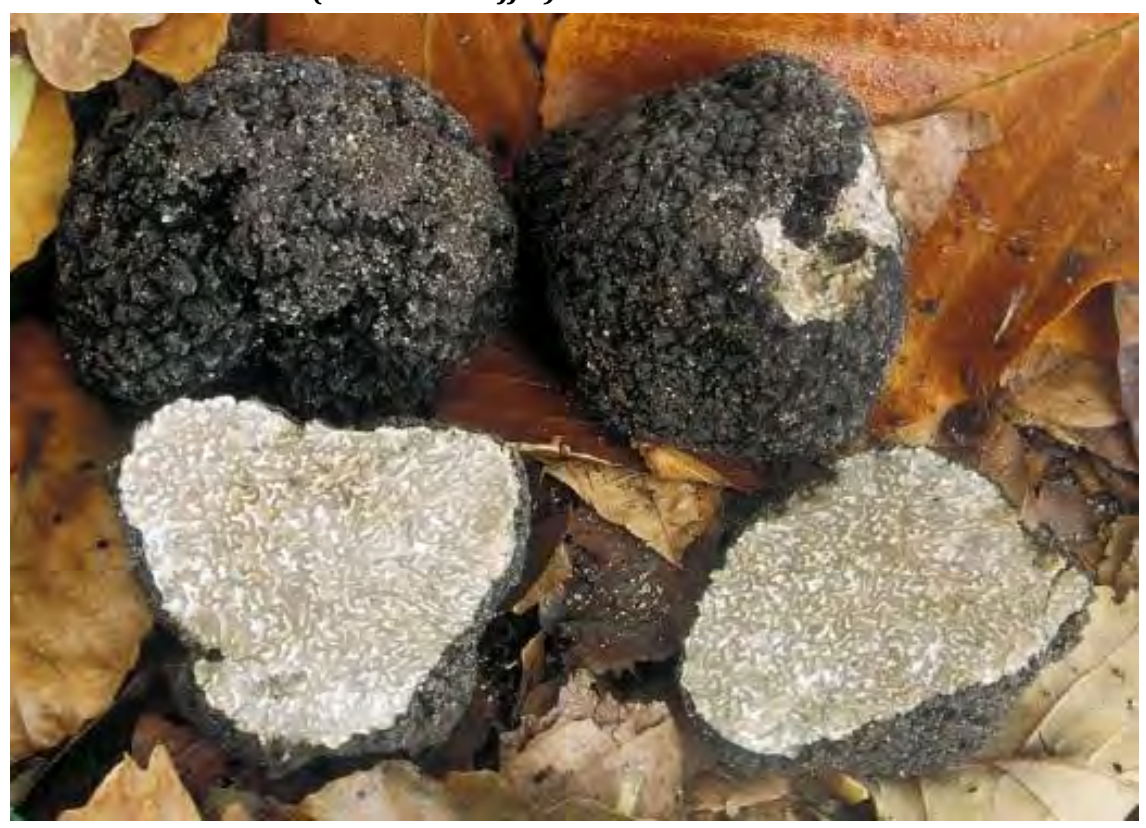

Red-listed in Denmark as near threatened.

Should only be marketed in the Nordic countries, if it is from countries, where it isnot red-listed. 


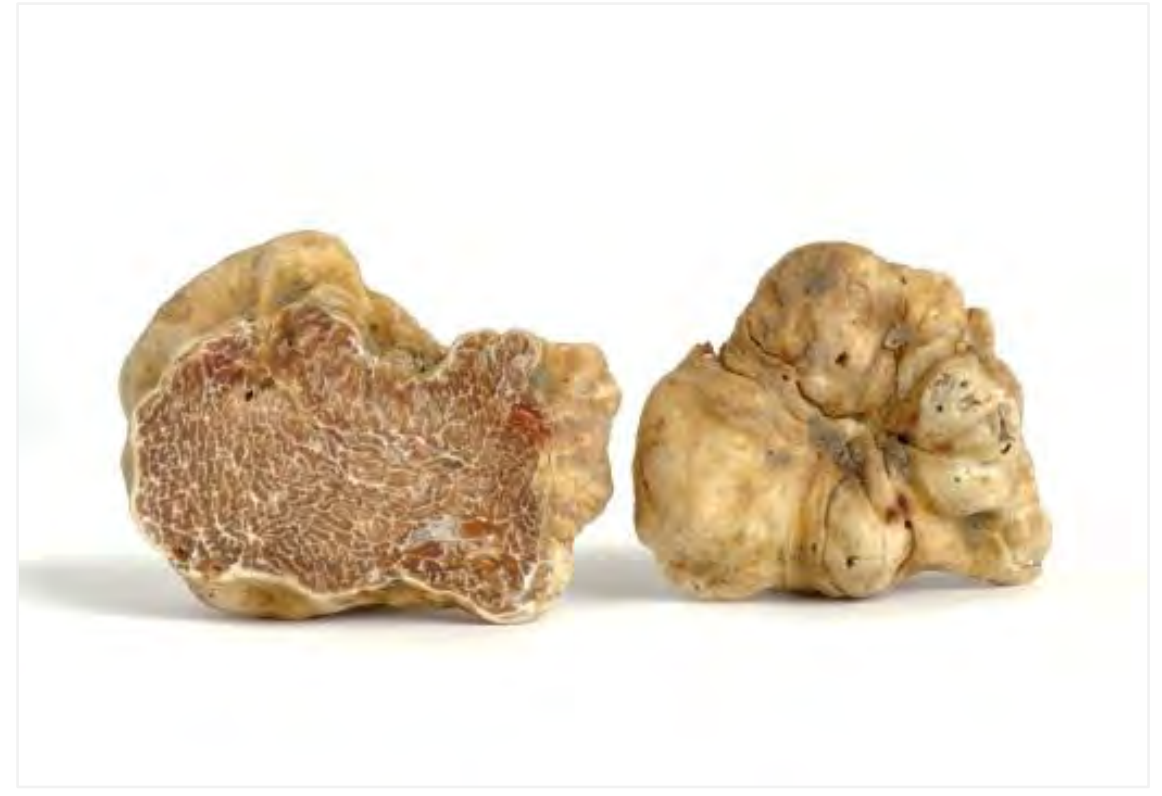

1-37 Tuber melanosporum ("Black Truffle”, “Black Winter Truffle”) 
1-38 Tuber sinense ("Chinese truffle" (Tuber indicum))

Picture missing

1-39 Volvariella volvacea (Volvaria volvacea)("Paddy Straw Mushroom", "Straw Mushroom")

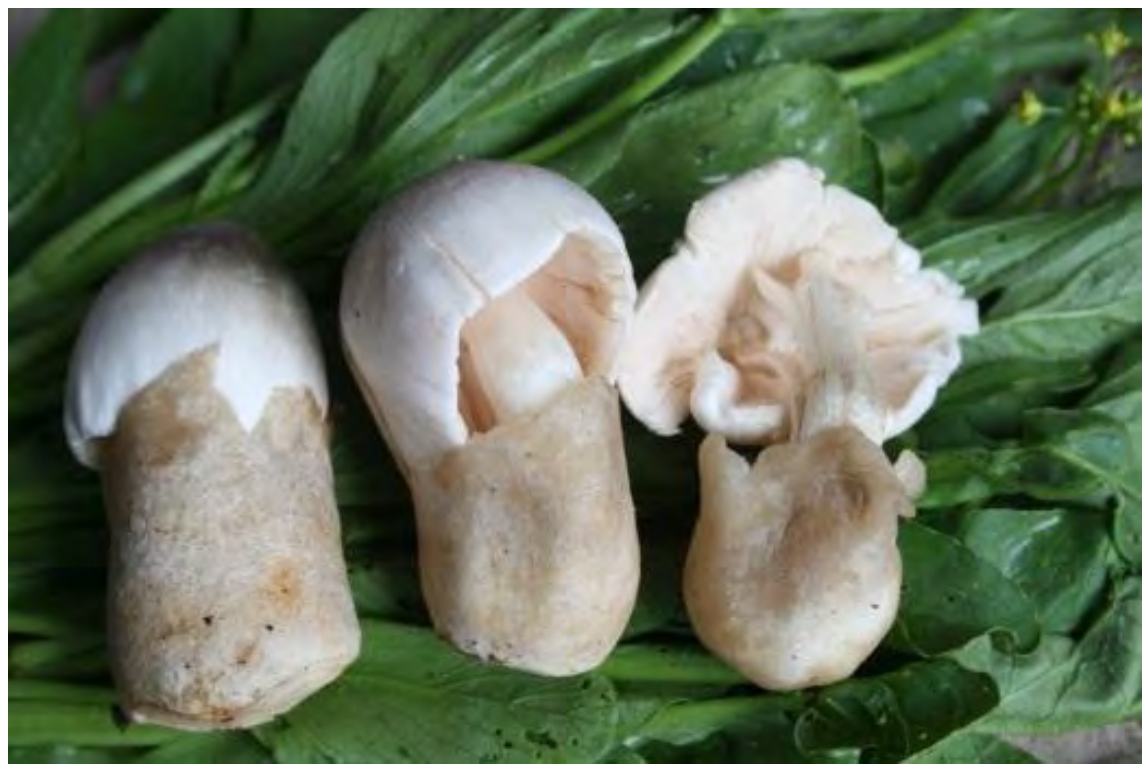


In the following lists, pictures are not included. Pictures of these mushrooms are in Volume II, section 2, see www.norden.org

\section{List 2}

Wild edible mushrooms, where the identity has to be documented by recognised experts, to be suitable for commercial marketing

\begin{tabular}{|c|c|c|c|}
\hline No. & Scientific name & English name & Comments \\
\hline $2-01$ & Agaricus arvensis & Horse Mushroom & $\begin{array}{l}\text { As Horse Mushroom efficiently bioaccumu- } \\
\text { lates cadmium, the content of this toxic } \\
\text { and carcinogenic metal should be regularly } \\
\text { controlled. } \\
\text { Due to the potentially high levels of phe- } \\
\text { nylhydrazine derivatives and cadmium, } \\
\text { Horse Mushroom should not be eaten in } \\
\text { larger amounts (see } A \text {. bisporus (Button } \\
\text { Mushroom) risk assessment). } \\
\text { The cultivated Horse Mushroom is in list } 1 .\end{array}$ \\
\hline $2-02$ & Agaricus augustus & The Prince & $\begin{array}{l}\text { As The Prince efficiently bioaccumulates } \\
\text { cadmium, the content of this toxic and } \\
\text { carcinogenic metal should be regularly } \\
\text { controlled. } \\
\text { Due to the potentially high levels of } \\
\text { phenylhydrazine derivatives and cadmi- } \\
\text { um, The Prince should not be eaten in } \\
\text { larger amounts (see } A \text {. bisporus (Button } \\
\text { Mushroom) risk assessment). }\end{array}$ \\
\hline $2-03$ & Agaricus bitorquis & Pavement Mushroom & $\begin{array}{l}\text { Due to the potentially high levels of } \\
\text { phenylhydrazine derivatives, Pavement } \\
\text { Mushroom should not be eaten in larger } \\
\text { amounts (see } A \text {. bisporus (Button Mush- } \\
\text { room) risk assessment). }\end{array}$ \\
\hline $2-04$ & Agaricus campestris & Field Mushroom & $\begin{array}{l}\text { Due to the potentially high levels of } \\
\text { phenylhydrazine derivatives, Field Mush- } \\
\text { room should not be eaten in larger } \\
\text { amounts (see } A \text {. bisporus (Button Mush- } \\
\text { room) risk assessment). }\end{array}$ \\
\hline $2-05$ & $\begin{array}{l}\text { Agaricus species, other not } \\
\text { yellowing e.g. A. langei } \\
\text { (A. haemorrhoidarius) and } \\
\text { A. sylvaticus }\end{array}$ & $\begin{array}{l}\text { Agaricus species, other not } \\
\text { yellowing e.g. Scaly Wood } \\
\text { Mushroom and Blushing } \\
\text { Wood Mushroom }\end{array}$ & $\begin{array}{l}\text { Due to the potentially high levels of } \\
\text { phenylhydrazine derivatives, other not } \\
\text { yellowing Agaricus species (e.g. Scaly } \\
\text { Wood Mushroom and Blushing Wood } \\
\text { Mushroom) should not be eaten in larger } \\
\text { amounts (see } A \text {. bisporus (Button Mush- } \\
\text { room) risk assessment). }\end{array}$ \\
\hline $2-06$ & $\begin{array}{l}\text { Agaricus species, other } \\
\text { yellowing e.g. A. sylvicola } \\
\text { (A. abruptibulbus) and } \\
\text { A. urinascens (A. excellens, } \\
\text { A. macrosporus) }\end{array}$ & $\begin{array}{l}\text { Agaricus species, other } \\
\text { yellowing } \\
\text { e.g. Wood Mushroom and } \\
\text { Macro Mushroom }\end{array}$ & $\begin{array}{l}\text { As yellowing, edible Agaricus species e.g. } \\
\text { Wood Mushroom and Macro Mushroom } \\
\text { efficiently bioaccumulate cadmium, the } \\
\text { content of this toxic and carcinogenic } \\
\text { metal should be regularly controlled } \\
\text { Due to their potential high levels of } \\
\text { phenylhydrazine derivatives, yellowing, } \\
\text { edible Agaricus species should not be } \\
\text { eaten in larger amounts (see } A \text {. bisporus } \\
\text { (Button Mushroom) risk assessment). }\end{array}$ \\
\hline $2-07$ & $\begin{array}{l}\text { Calocybe gambosa } \\
\text { (Lyophyllum gambosum) } \\
\text { (Tricholoma gambosum, } \\
\text { T. georgii) }\end{array}$ & St. George's Mushroom & \\
\hline
\end{tabular}




\begin{tabular}{|c|c|c|c|}
\hline No. & Scientific name & English name & Comments \\
\hline $2-08$ & Coprinus comatus & $\begin{array}{l}\text { Shaggy Inkcap, Lawyer's } \\
\text { Wig, (Shaggy Mane) }\end{array}$ & \\
\hline $2-09$ & $\begin{array}{l}\text { Cortinarius caperatus } \\
\text { (Rozites caperatus) }\end{array}$ & The Gypsy & \\
\hline $2-10$ & Flammulina velutipes & $\begin{array}{l}\text { Velvet Shank } \\
\text { (Golden Needle Mush- } \\
\text { room) }\end{array}$ & The cultivated Velvet Shank is in list 1. \\
\hline $2-11$ & Gomphidius glutinosus & Slimy Spike & \\
\hline $2-12$ & Gomphus clavatus & Pig's Ear & $\begin{array}{l}\text { Red-listed in Denmark and in Sweden as } \\
\text { vulnerable and in Norway as near threat- } \\
\text { ened. } \\
\text { Should only be marketed in the Nordic } \\
\text { countries, if it is from countries, where it } \\
\text { is not red-listed. }\end{array}$ \\
\hline $2-13$ & $\begin{array}{l}\text { Hygrocybe pratensis } \\
\text { (Camarophyllus pratensis) }\end{array}$ & Meadow Waxcap (Buffcap) & \\
\hline $2-14$ & Hygrocybe punicea & Crimson Waxcap & $\begin{array}{l}\text { Red-listed as near threatened in Sweden } \\
\text { and Denmark. } \\
\text { Should only be marketed in the Nordic } \\
\text { countries, if it is from countries, where it } \\
\text { is not red-listed. }\end{array}$ \\
\hline $2-15$ & Hygrophorus camarophyllus & Arched Woodwax & $\begin{array}{l}\text { Red-listed in Denmark as critically endan- } \\
\text { gered. } \\
\text { Should only be marketed in the Nordic } \\
\text { countries, if it is from countries, where it } \\
\text { is not red-listed. }\end{array}$ \\
\hline $2-16$ & Hygrophorus hypothejus & Herald of Winter & \\
\hline $2-17$ & Lactarius deliciosus & Saffron Milkcap & \\
\hline $2-18$ & Lactarius deterrimus & False Saffron Milkcap & \\
\hline $2-19$ & Lactarius rufus & $\begin{array}{l}\text { Rufous Milkcap } \\
\text { (Red Hot Milkcap) }\end{array}$ & $\begin{array}{l}\text { Need to be pre-treated (salted/heat } \\
\text { treated) to destroy the acrid substances in } \\
\text { the mushroom. Cooking water should be } \\
\text { discarded. }\end{array}$ \\
\hline $2-20$ & Lactarius torminosus & Woolly Milkcap & $\begin{array}{l}\text { Need to be pre-treated (salted/heat } \\
\text { treated) to destroy the acrid substances in } \\
\text { the mushroom. Cooking water should be } \\
\text { discarded. }\end{array}$ \\
\hline $2-21$ & $\begin{array}{l}\text { Lactarius trivialis. } \\
\text { (L.s utilis) }\end{array}$ & No English name & $\begin{array}{l}\text { Need to be pre-treated (salted/heat } \\
\text { treated) to destroy theacrid substances in } \\
\text { the mushroom. Cooking water should be } \\
\text { discarded. } \\
\text { Red-listed as near threatened in Denmark. } \\
\text { Should only be marketed in the Nordic } \\
\text { countries, if it is from countries, where it } \\
\text { is not red-listed. }\end{array}$ \\
\hline $2-22$ & Lactarius volemus & $\begin{array}{l}\text { Fishy Milkcap } \\
\text { (Weeping Milkcap) }\end{array}$ & $\begin{array}{l}\text { Red-listed in Denmark } \\
\text { Should only be marketed in the Nordic } \\
\text { countries, if it is from countries, where it } \\
\text { is not red-listed }\end{array}$ \\
\hline $2-23$ & $\begin{array}{l}\text { Leccinum aurantiacum } \\
\text { (L. albostipitatum, L. } \\
\text { quercinum) }\end{array}$ & $\begin{array}{l}\text { Orange Aspen Bolete } \\
\text { (Orange Oak Bolete) }\end{array}$ & $\begin{array}{l}\text { Thorough heat treatment is necessary as } \\
\text { insufficiently cooked mushrooms can give } \\
\text { intoxications. }\end{array}$ \\
\hline $2-24$ & $\begin{array}{l}\text { Leccinum species, other } \\
\text { e.g. L. Scabrum }\end{array}$ & $\begin{array}{l}\text { Leccinum species, other } \\
\text { species, e.g. Brown Birch } \\
\text { Bolete }\end{array}$ & $\begin{array}{l}\text { Thorough heat treatment is necessary as } \\
\text { insufficiently cooked mushrooms can give } \\
\text { intoxications. }\end{array}$ \\
\hline $2-25$ & Leccinum versipelle & Orange Birch Bolete & $\begin{array}{l}\text { Thorough heat treatment is necessary as } \\
\text { insufficiently cooked mushrooms can give } \\
\text { intoxications. }\end{array}$ \\
\hline $2-26$ & Leccinum vulpinum & Foxy Bolete & $\begin{array}{l}\text { Thorough heat treatment is necessary as } \\
\text { insufficiently cooked mushrooms can give } \\
\text { intoxications. }\end{array}$ \\
\hline
\end{tabular}




\begin{tabular}{|c|c|c|c|}
\hline No. & Scientific name & English name & Comments \\
\hline $2-27$ & $\begin{array}{l}\text { Lepista nuda } \\
\text { (Tricholoma nudum) }\end{array}$ & Wood Blewit & The cultivated Wood Blewit is in list 1. \\
\hline $2-28$ & $\begin{array}{l}\text { Lepista saeva } \\
\text { (L.personata, Tricholoma } \\
\text { personatum) }\end{array}$ & Field Blewit & \\
\hline $2-29$ & $\begin{array}{l}\text { Russula claroflava } \\
\text { (R. flava) }\end{array}$ & Yellow Swamp Brittlegill & \\
\hline $2-30$ & Russula decolorans & Copper Brittlegill & \\
\hline $2-31$ & Russula integra & Nutty Brittlegill & \\
\hline $2-32$ & Russula paludosa & (“Tall Brittlegill”) & \\
\hline $2-33$ & Russula vesca & $\begin{array}{l}\text { The Flirt } \\
\text { (Bare-toothed Russula ) }\end{array}$ & \\
\hline $2-34$ & $\begin{array}{l}\text { Russula vinosa } \\
\text { (R. obscura) }\end{array}$ & Darkening Brittlegill & \\
\hline $2-35$ & Russula xerampelina & $\begin{array}{l}\text { Crab Brittlegill (Shrimp } \\
\text { Mushroom) }\end{array}$ & $\begin{array}{l}\text { There are more species, closely related to } \\
\text { Crab Brittlegill. Like this mushroom, they } \\
\text { smell of cooked shellfish and are edible, } \\
\text { but they are not common in the Nordic } \\
\text { countries. }\end{array}$ \\
\hline $2-36$ & Suillus granulatus & $\begin{array}{l}\text { Weeping Bolete (Granula- } \\
\text { ted Bolete) }\end{array}$ & \\
\hline $2-37$ & Suillus grevillei & $\begin{array}{l}\text { Larch Bolete (Greville's } \\
\text { Bolete) }\end{array}$ & \\
\hline $2-38$ & Suillus variegatus & $\begin{array}{l}\text { Velvet Bolete (Variegated } \\
\text { Bolete, } \\
\text { "Swedish Jack") }\end{array}$ & \\
\hline $2-39$ & Tricholoma portentosum & $\begin{array}{l}\text { Charbonnier } \\
\text { (“The Coalman") }\end{array}$ & \\
\hline $2-40$ & $\begin{array}{l}\text { Xerocomus badius } \\
\text { (Boletus badius) }\end{array}$ & Bay Bolete & \\
\hline
\end{tabular}




\section{List 3}

Wild mushrooms, which may easily be mistaken for poisonous look-alikes and therefore are not regarded as suitable for commercial marketing

\begin{tabular}{|c|c|c|c|}
\hline No. & Scientific name & English name & Comments \\
\hline $3-01$ & Amanita fulva & $\begin{array}{l}\text { Tawny Grisette } \\
\text { (Orange-Brown Ringless } \\
\text { Amanita) }\end{array}$ & $\begin{array}{l}\text { Immature Tawny Grisette (especially } \\
\text { when it looks like "small hen's eggs") may } \\
\text { be mistaken for the deadly poisonous } \\
\text { Deathcap ( } A \text {. phalloides) or Destroying } \\
\text { Angel ( } A \text {. virosa) which also may look like } \\
\text { "small hen's eggs", when they are very } \\
\text { young). }\end{array}$ \\
\hline $3-02$ & Amanita rubescens & Blusher & $\begin{array}{l}\text { The Blusher resembles Panthercap } \\
\text { (A. pantherina), which is very poisonous. }\end{array}$ \\
\hline $3-03$ & Armillaria borealis & No English name & The "Honey Fungus species" should never \\
\hline $3-04$ & $\begin{array}{l}\text { Armillaria cepistipes } \\
\text { (Armillariella cepistipes) }\end{array}$ & No English name & $\begin{array}{l}\text { be eaten raw, should be thoroughly } \\
\text { cooked, and should only be eaten in small }\end{array}$ \\
\hline $3-05$ & $\begin{array}{l}\text { Armillaria lutea } \\
\text { (Armillaria gallica) }\end{array}$ & Bulbous Honey Fungus & $\begin{array}{l}\text { amounts, when eaten for the first time, } \\
\text { However, "Honey Fungus species"are very }\end{array}$ \\
\hline $3-06$ & $\begin{array}{l}\text { Armillaria mellea } \\
\text { (Armillariella mellea) }\end{array}$ & Honey Fungus & $\begin{array}{l}\text { difficult to distinguish from the toxic Dark } \\
\text { Honey Fungus ( } A \text {. ostoyae), and should } \\
\text { therefore not be used for marketing. } \\
\text { For the time being (June 2012) Armillaria } \\
\text { species are leagally marketed in Finland, } \\
\text { but the status is subject to change. }\end{array}$ \\
\hline $3-07$ & Boletus luridiformis & $\begin{array}{l}\text { Scarletina Bolete } \\
\text { (Dotted-Stemmed Bolete) }\end{array}$ & $\begin{array}{l}\text { Resembles Devils Bolete (B. satanas) and } \\
\text { B. legaliae which are both poisonous. }\end{array}$ \\
\hline $3-08$ & Boletus luridus. & Lurid Bolete & $\begin{array}{l}\text { Resembles Devils Bolete (B. satanas) and } \\
\text { B. legaliae which are both poisonous. }\end{array}$ \\
\hline $3-09$ & $\begin{array}{l}\text { Chlorophyllum olivieri } \\
\text { (Lepiota olivieri, } \\
\text { Macrolepiota olivieri) }\end{array}$ & No English name & $\begin{array}{l}\text { Resembles Chlorophyllum brunneum } \\
\text { which is suspected to be poisonous. }\end{array}$ \\
\hline $3-10$ & $\begin{array}{l}\text { Chlorophyllum rachodes } \\
\text { (Macrolepiota rachodes, } \\
\text { Lepiota) }\end{array}$ & Shaggy Parasol & $\begin{array}{l}\text { Resembles Chlorophyllum brunneum } \\
\text { which is suspected to be poisonous. }\end{array}$ \\
\hline $3-11$ & Clitopilus prunulus & The Miller & $\begin{array}{l}\text { Resembles some small Funnel species } \\
\text { (Clitocybe species) like Fools Funnel (Clito- } \\
\text { cybe rivulosa) which are very poisonous. }\end{array}$ \\
\hline $3-12$ & $\begin{array}{l}\text { Cortinarius spp. e.g. } \\
\text { Cortinarius armillatus }\end{array}$ & $\begin{array}{l}\text { Webcap species e.g. Red } \\
\text { Banded Webcap }\end{array}$ & $\begin{array}{l}\text { Many webcaps (Cortinarius species) are } \\
\text { difficult to identify, and some of them are } \\
\text { deadly poisonous, e.g., Deadly Webcap } \\
\text { (Cortinarius rubellus). }\end{array}$ \\
\hline $3-13$ & Hypholoma capnoides & Conifer Tuft & $\begin{array}{l}\text { Conifer Tuft (Hypholoma capnoides) } \\
\text { resembles Sulphur Tuft (Hypholoma } \\
\text { fasciculare) which is poisonous. }\end{array}$ \\
\hline $3-14$ & $\begin{array}{l}\text { Kuehneromyces mutabilis } \\
\text { (Pholiota mutabilis) }\end{array}$ & $\begin{array}{l}\text { Sheathed Woodtuft } \\
\text { ("Two-tone Pholiote") }\end{array}$ & $\begin{array}{l}\text { Sheathed Woodtuft (Kuehneromyces } \\
\text { mutabilis) resembles Funeral Bell (Galeri- } \\
\text { na marginata) which is deadly poisonous. }\end{array}$ \\
\hline $3-15$ & $\begin{array}{l}\text { Russula aeruginea } \\
\text { and other glaucous green } \\
\text { Russula species, e.g. } \\
\text { Russula cyanoxantha } \\
\text { Russula grisea } \\
\text { Russula ionochlora } \\
\text { Russula parazurea } \\
\text { Russula virescens. }\end{array}$ & $\begin{array}{l}\text { Green Brittlegill and other } \\
\text { Brittlegill species e.g. } \\
\text { Charcoal Burner } \\
\text { No English name } \\
\text { Oilslick Brittlegill } \\
\text { Powdery Brittlegill } \\
\text { Greencracked Brittlegill }\end{array}$ & $\begin{array}{l}\text { Green Brittlegill (Russula aeruginea) and } \\
\text { other glaucous green Brittlegill species } \\
\text { resemble Deathcap (Amanita phalloides) } \\
\text { which is deadly poisonous. }\end{array}$ \\
\hline
\end{tabular}




\section{List 4}

Wild mushrooms earlier regarded as edible, but which are suspected to cause acute or long-time adverse effects after ingestion and therefore not regarded as suitable for commercial marketing

\begin{tabular}{|c|c|c|c|}
\hline No. & Scientific Name & English name & Comments \\
\hline $4-01$ & $\begin{array}{l}\text { Armillaria ostoyae } \\
\text { (Armillarialla ostroyae.) }\end{array}$ & Dark Honey Fungus & $\begin{array}{l}\text { May give rise to intoxications, even if } \\
\text { thoroughly cooked and should therefore } \\
\text { not be used in commercial trade. } \\
\text { The toxicant is not known. } \\
\text { For the time being (June 2012) "Honey } \\
\text { Fungus species" (Armillaria species) are } \\
\text { legally marketed in Finland, but the status } \\
\text { is subject to change. }\end{array}$ \\
\hline $4-02$ & $\begin{array}{l}\text { Clitocybe connata } \\
\text { (Lyophyllum connatum) }\end{array}$ & White Domecap & \\
\hline $4-03$ & $\begin{array}{l}\text { Clitocybe nebularis } \\
\text { (Lepista nebularis) }\end{array}$ & Clouded Funnel & $\begin{array}{l}\text { Gives rise to intoxincation in some peo- } \\
\text { ple, even after thorough cooking. The } \\
\text { toxicant is not known. }\end{array}$ \\
\hline $4-04$ & $\begin{array}{l}\text { Coprinopsis atramentaria } \\
\text { (Coprinus atramentarius) }\end{array}$ & Common Inkcap & $\begin{array}{l}\text { Contains coprin, a toxin with "antabus"- } \\
\text { like effects and with suspected reproduc- } \\
\text { tive toxic effects. }\end{array}$ \\
\hline $4-05$ & Gyromitra esculenta & $\begin{array}{l}\text { False Morel } \\
\text { (Turban, Brain Mush- } \\
\text { room) }\end{array}$ & $\begin{array}{l}\text { Should not be consumed as it even after } \\
\text { months of drying or after repeated boiling } \\
\text { and discarding of the water, still contains } \\
\text { significant amounts of suspected genotox- } \\
\text { ic and carcinogenic hydrazinderivatives. }\end{array}$ \\
\hline $4-06$ & Laccaria amethystina & Amethyst Deceiver & $\begin{array}{l}\text { Accumulates arsenic, and contains organic } \\
\text { arsenic compounds, especially dimethylar- } \\
\text { sinic acid, which cannot be excluded to be } \\
\text { genotoxic and carcinogenic. }\end{array}$ \\
\hline $4-07$ & $\begin{array}{l}\text { Lactarius necator } \\
\text { (L. plumbeus, L. turpis) }\end{array}$ & Ugly Milkcap & $\begin{array}{l}\text { Contains the heat stable necatorin which } \\
\text { is suspected to be genotoxic. }\end{array}$ \\
\hline $4-08$ & Paxillus involutus & $\begin{array}{l}\text { Brown Rollrim } \\
\text { (Common Rollrim, } \\
\text { Poison Pax) }\end{array}$ & $\begin{array}{l}\text { Contains potent, but unknown toxicant(s), } \\
\text { which are not efficiently destroyed after } \\
\text { cooking, and which after repeated meals } \\
\text { may give severe adverse reactions, in } \\
\text { some cases deadly. }\end{array}$ \\
\hline $4-09$ & Pholiota squarrosa & Shaggy Scalycap & $\begin{array}{l}\text { May occationally give rise to intoxications. } \\
\text { The toxicant is unknown. }\end{array}$ \\
\hline $4-10$ & Pleurocybella porrigens & Angel's Wings & $\begin{array}{l}\text { Contains pleurocybellaziridine which has } \\
\text { given rise to several fatal intoxications. }\end{array}$ \\
\hline $4-11$ & $\begin{array}{l}\text { Tricholoma equestre } \\
\text { (T. flavovirens, T. auratum) }\end{array}$ & $\begin{array}{l}\text { Yellow Knight (Man on } \\
\text { Horseback, } \\
\text { "Canary Mushroom") }\end{array}$ & $\begin{array}{l}\text { Severe, also some fatal intoxicantions } \\
\text { have been reported after consumption of } \\
\text { repeated meals with substantial amounts } \\
\text { of this mushroom. Yellow Knight should } \\
\text { not be marketed before occurrence and } \\
\text { identity of the toxicant(s) has been } \\
\text { elucidated and not before the mecanism } \\
\text { of the toxicity has been explaned. } \\
\text { Due to the intoxications, some European } \\
\text { countries have forbidden trade with } \\
\text { Yellow Knight. }\end{array}$ \\
\hline
\end{tabular}

${ }^{6}$ May under specified conditions be marketed in Finland and Sweden, see risk assessment of False Morel

(Gyromitra esculenta), Volume II, section 2. 


\section{Index to the lists}

The numbers in the index are constructed as follows:

- Number 1-01 refers to list 1 , mushroom no 01 ,

- Number 2-01 refers to list 2, mushroom no 01 etc.

Some of the mushrooms on the lists have not ${ }^{7}$ a name in English, and are in the index under "No English names".

\begin{tabular}{|c|c|c|}
\hline English name & Scientific name & No \\
\hline Agaricus species, other not yellowing & Agaricus species, other not yellowing & $2-05$ \\
\hline Agaricus species other yellowing & Agaricus species, other yellowing & $2-06$ \\
\hline Alba Truffle & Tuber magnatum & $1-36$ \\
\hline Amethyst Deceiver & Laccaria amethystina & $4-06$ \\
\hline Angel's Wings & Pleurocybella porringens & $4-10$ \\
\hline Arched Woodwax & Hygrophorus camarophyllus & $2-15$ \\
\hline Autumn Chanterelle & Craterellus lutescens & $1-13$ \\
\hline Bare-toothed Russula & Russula vesca & $2-33$ \\
\hline Bay Bolete & Xerocomus badius & $2-40$ \\
\hline Bearded Tooth & Hericium erinaceus & $1-18$ \\
\hline Black Chanterelle & Craterellus cornucopioides & $1-12$ \\
\hline Black Morel & Morchella conica & $1-25$ \\
\hline Black Truffle & Tuber melanosporum & $1-37$ \\
\hline Black Trumpet & Craterellus cornucopioides & $1-12$ \\
\hline Black Winter Truffle & Tuber melanosporum & $1-37$ \\
\hline Blusher & Amanita rubescens & $3-02$ \\
\hline Blushing Wood Mushroom & Agaricus sylvaticus & $2-05$ \\
\hline Brain Mushroom & Gyromitra esculenta. & $4-05$ \\
\hline Brown Beech Mushroom & Hypsizygus tessulatus & $1-24$ \\
\hline Brown Birch Bolete & Leccinum scabrum & $2-24$ \\
\hline Brown Rollrim & Paxillus involutus & $4-08$ \\
\hline Brown Shimeji & Hypsizygus spp. & $1-21$ \\
\hline Buffcap & Hygrocybe pratensis & $2-13$ \\
\hline Bulbous Honey Fungus & Armillaria lutea & $3-05$ \\
\hline Button Mushroom & Agaricus bisporus & $1-02$ \\
\hline Caesar's Amanita & Amanita caesarea & $1-04$ \\
\hline Caesar's Mushroom & Amanita caesarea & $1-04$ \\
\hline Chanterelle Gris & Craterllus cornucopoides & $1-14$ \\
\hline Chanterelle Jaune & Craterellus lutenscens & $1-13$ \\
\hline Charbonnier & Tricholoma portentosum & $2-39$ \\
\hline Charcoal Burner & Russula cyanoxantha & $2-15$ \\
\hline Chinese truffle & Tuber indicum & $1-38$ \\
\hline Clouded Funnel & Clitocybe nebularis & $4-03$ \\
\hline Common Inkcap & Coprinopsis atramentaria & $4-04$ \\
\hline
\end{tabular}

${ }^{7}$ April 2012. 


\begin{tabular}{|c|c|c|}
\hline English name & Scientific name & No \\
\hline Common Rollrim & Paxillus involutus & $4-08$ \\
\hline Conifer Tuft & Hypholoma capnoides & $3-13$ \\
\hline Copper Brittlegill & Russula decolorans & $2-30$ \\
\hline Coral Tooth & Hericium coralloides & $1-17$ \\
\hline Cortinarius species & Cortinarius spp. & $3-12$ \\
\hline Crab Brittlegill & Russula xerampelina & $2-35$ \\
\hline Crimson Waxcap & Hygrocybe punicea & $2-14$ \\
\hline Cultivated Mushroom & Agaricus bisporus & $1-02$ \\
\hline Darkening Brittlegill & Russula vinosa & $2-34$ \\
\hline Dark Honey Fungus & Armillaria ostoyae & $4-01$ \\
\hline Dotted-Stemmed Bolete & Boletus luridiformis & $3-07$ \\
\hline Ear species & Auricularia polytricha & $1-06$ \\
\hline Elm Leech & Hypsizygus spp. & $1-21$ \\
\hline Enoki-take & Flammulina velutipes & $1-15,2-10$ \\
\hline False Morel & Gyromitra esculenta. & $4-04$ \\
\hline False Saffron Milkcap & Lactarius deterrimus & $2-16$ \\
\hline Field Blewit & Lepista saeva & $2-28$ \\
\hline Field Mushroom & Agaricus campestris & $2-04$ \\
\hline Fishy Milkcap & Lactarius volemus & $2-22$ \\
\hline Foxy Bolete & Leccinum vulpinum & $2-26$ \\
\hline Forest Lamb & Albatrellus ovinus & $1-03$ \\
\hline French Horn Mushroom & Pleurotus eryngii & $1-30$ \\
\hline Girolle & Cantharellus cibarius & $1-10$ \\
\hline Golden Chanterelle & Craterellus lutescens & $1-13$ \\
\hline Golden Needle Mushroom & Flammulina velutipes & $1-15,2-10$ \\
\hline Granulated Bolete & Suillus granulatus & $2-36$ \\
\hline Green Brittlegill & Russula aeruginea & $3-15$ \\
\hline Greencracked Brittlegill & Russula virescens & $3-15$ \\
\hline Greville's Bolete & Suillus grevillei & $2-37$ \\
\hline Hedgehog & Hydnum repandum & $1-19$ \\
\hline Hen of the Woods & Grifola frondosa & $1-16$ \\
\hline Herald of Winter & Hygrophorus hypothejus & $2-16$ \\
\hline Honey Fungus & Armillaria mellea & $3-06$ \\
\hline Horn of Plenty & Craterellus cornucopioides & $1-12$ \\
\hline Horse Mushroom & Agaricus arvensis & $1-01,2-01$ \\
\hline Jelly ear & Auricularia auricula-judae & $1-05$ \\
\hline Jew's Ear & Auricularia auricula-judae & $1-05$ \\
\hline Judas's Ear Fungus & Auricularia auricula-judae & $1-05$ \\
\hline King Oyster & Pleurotus eryngii & $1-30$ \\
\hline King Trumpet Mushroom & Pleurotus eryngii & $1-30$ \\
\hline Larch Bolete & Suillus grevillei & $2-37$ \\
\hline Lawyer's Wig & Coprinus comatus & $2-08$ \\
\hline Leccinum species, other & Leccinum species other & $2-24$ \\
\hline Lion's Mane Mushroom & Hericium erinaceus & $1-18$ \\
\hline Lurid Bolete & Boletus luridus & $3-08$ \\
\hline Macro Mushroom & Agaricus urinascens & $2-06$ \\
\hline Man on Horseback & Tricholoma equestre & $4-11$ \\
\hline Matsu-take & Tricholoma matsutake & $1-34$ \\
\hline Meadow Waxcap & Hygrocybe pratensis & $2-13$ \\
\hline Morel & Morchella conica & $1-25$ \\
\hline Morel & Morchella esculenta & $1-26$ \\
\hline Nameko & Pholiota nameko & $1-27$ \\
\hline No English name & Armillaria borealis & $3-03$ \\
\hline No English name & Armillaria cepistipes & $3-04$ \\
\hline No English name & Cantharellus pallens & $1-11$ \\
\hline No English name & Chlorophyllum olivieri & $3-09,3-10$ \\
\hline No English name & Lactarius trivialis & $2-21$ \\
\hline No English name & Leccinum aurantiacum & $2-23$ \\
\hline No English name & Russula grisea & $3-15$ \\
\hline Nutty Brittlegill & Russula integra & $2-31$ \\
\hline Oilslick Brittlegill & Russula ionochlora & $3-15$ \\
\hline Orange Aspen Bolete & Leccinum aurantiacum & $2-23$ \\
\hline
\end{tabular}




\begin{tabular}{|c|c|c|}
\hline English name & Scientific name & No \\
\hline Orange Birch Bolete & Leccinum versipelle & $2-25$ \\
\hline Orange-Brown Ringless Amanita & Amanita fulva & $3-01$ \\
\hline Orange Oak Bolete & Leccinum aurantiacum & $2-23$ \\
\hline Oyster Mushroom & Pleurotus ostreatus & $1-31$ \\
\hline Paddy Straw Mushroom & Volvariella volvacea & $1-39$ \\
\hline Parasol & Macrolepiota procera & $1-24$ \\
\hline Pavement Mushroom & Agaricus bitorquis & $2-03$ \\
\hline Penny Bun & Boletus edulis & $1-07$ \\
\hline Pholiote & Pholiota nameko & $1-27$ \\
\hline Pied de Mouton & Hydnum repandum & $1-19$ \\
\hline Pig's Ear & Gomphus clavatus & $2-11$ \\
\hline Pine Bolete & Boletus pinophilus & $1-08$ \\
\hline Pine Cep & Boletus pinophilus & $1-08$ \\
\hline Pink Oyster Mushroom & Pleurotus djamor & $1-29$ \\
\hline Pointed Morel & Morchella conica & $1-25$ \\
\hline Poison Pax & Paxillus involutus & $4-08$ \\
\hline Pom Pom & Hericium erinaceus & $1-18$ \\
\hline Powdery Brittlegill & Russula parazurea & $3-15$ \\
\hline Red Banded Webcap & Cortinarius spp. e.g., Cortinarius armillatus & $3-12$ \\
\hline Red Hot Milkcap & Lactarius rufus & $2-19$ \\
\hline Ribbed Morel & Morchella conica & $1-25$ \\
\hline Powdery Brittlegill & Russula parazurea & $3-15$ \\
\hline Rufous Milkcap & Lactarius rufus & $2-19$ \\
\hline Saffron Milkcap & Lactarius deliciosus & $2-17$ \\
\hline Scaly Wood Mushroom & Agaricus langei & $2-05$ \\
\hline Scarletina Bolete & Boletus luridiformis & $3-07$ \\
\hline Shaggy Inkcap & Coprinus comatus & $2-08$ \\
\hline Shaggy Mane & Coprinus comatus & $2-08$ \\
\hline Shaggy Parasol & Chlorophyllum rachodes & $3-10$ \\
\hline Shaggy Scalycap & Pholiota squarrosa & $4-09$ \\
\hline Sheathed Woodtuft & Kuehneromyces mutabilis & $3-14$ \\
\hline Shii-take & Lentinula edodes & $1-22$ \\
\hline Shrimp Mushroom & Russula xerampelina & $2-35$ \\
\hline Slimy Spike & Gomphidius glutinosus & $2-11$ \\
\hline Slippery Jack & Suillus luteus & $1-32$ \\
\hline Spicy Knight & Tricholoma matsutake & $1-34$ \\
\hline St. George's Mushroom & Calocybe gambosa & $2-07$ \\
\hline Straw Mushroom & Volvariella volvacea & $1-39$ \\
\hline Summer Bolete & Boletus reticulatus & $1-09$ \\
\hline Summer Truffle & Tuber aestivum & $1-35$ \\
\hline Swedish Bolete & Suillus variegatus & $2-38$ \\
\hline Tall Brittlegill & Russula paludosa & $2-32$ \\
\hline Tawny Grisette & Amanita fulva & $3-01$ \\
\hline Terracotta Hedgehog & Hydnum rufescens & $1-20$ \\
\hline The coalman & Tricholoma portentosum & $2-39$ \\
\hline The Flirt & Russula vesca & $2-33$ \\
\hline The Golden Oyster Mushroom & Pleurotus citrinopileatus & $1-28$ \\
\hline The Gypsy & Cortinarius caperatus & $2-09$ \\
\hline The Miller & Clitopilus prunulus & $3-11$ \\
\hline The Prince & Agaricus augustus & $2-02$ \\
\hline Trumpet Chantarelle & Craterellus tubaeformis & $1-14$ \\
\hline Turban & Gyromitra esculenta. & $4-05$ \\
\hline Two Tone Pholiote & Kuenhneromyces mutabilis & $3-14$ \\
\hline Ugly Milkcap & Lactarius necator & $4-07$ \\
\hline Variegated Bolete & Suillus variegatus & $2-38$ \\
\hline Velvet Bolete & Suillus variegatus & $2-38$ \\
\hline Velvet Shank & Flammulina velutipes & $1-15,2-10$ \\
\hline Webcap species & Cortinarius spp. & $3-12$ \\
\hline Weeping Bolete & Suillus granulatus & $2-36$ \\
\hline Weeping Milkcap & Lactarius volemus & $2-20$ \\
\hline White Beech Mushroom & Hypsizygus tessulatus & $1-21$ \\
\hline White Domecap & Clitocybe connata & $4-02$ \\
\hline White Shimeji & Hypzysygus spp. & $1-21$ \\
\hline
\end{tabular}




\begin{tabular}{lll}
\hline English name & Scientific name & No \\
\hline White Truffle & Tuber magnatum & $1-36$ \\
Winter Chanterelle & Craterellus cornucopoides & $1-14$ \\
Wood Blewit & Lepista nuda & $1-23,2-27$ \\
Wood Cauliflower & Sparassis crispa & $1-33$ \\
Wood Hedgehog & Hydnum repandum & $1-19$ \\
Wood Mushroom & Agaricus sylvicola & $2-06$ \\
Woolly Milkcap & Lactarius torminosus & $2-20$ \\
Yellow Foot & Craterellus lutescens & $1-13$ \\
Yellow Knight & Tricholoma equestre & $4-11$ \\
Yellow Swamp Brittlegill & Russula claroflava & $2-29$ \\
\hline
\end{tabular}




\section{Annex I - Overview on relevant EU and national legislation and in-house control}

\section{Legislation}

Foodstuffs are covered by general requirements in the legislation as well as specific requirements e.g. on heavy metals and radioactivity.

The control and requests of documentation from the trade and industry are regulated in a number of EU regulations and directives:

- General Food Law

- Food Labelling

- Novel Food

- Fruit and vegetables

- Contaminants in food (metals, pesticides, radioactivity)

- Hygiene

- Control

- National legislation or guidance on bioactive components

General Food Law: Mushrooms traded as food have to comply with the generals requirements in the European Food Regulation, especially article 14, saying that food shall not be placed on the market if it is unsafe. Furthermore, the following should be taken into account when assessing whether any food may be "injurious to health":

- not only to the probable immediate and/or short-term and/or longterm effects of that food on the health of a person consuming it, but also on subsequent generations

- to the probable cumulative toxic effects

- to the particular health sensitivities of a specific category of consumers where the food is intended for that category of consumers 
Novel Food Regulation: Regarding a growing market on mushroom species, it should be recognized, that in Europe, foods that are new on the European market are covered by the Novel Food regulation. This regulation states that foods that have not been consumed within the Community to a significant degree before 15 May 1997 should be considered a Novel Food. The Novel Foods have to be risk assessed before being allowed on the European market. It is a further complication that the intake of various mushroom species is not well documented.

National regulation on mushrooms: Some EU member states, like Sweden, Finland, Belgium, Poland and France have national legislation or guidance on edible mushrooms. The contents of inherent toxicants are not subject to harmonised legislation in the EU.

In-house control is defined as the systematic measures taken by the business operators to ensure that the requirements set out concerning edible mushrooms are fulfilled.

The basis for sustainable production or import is proper in-house control of mushrooms (and other types of foodstuffs) at the producers and importers. Control should be based on HACCP, through relevant documentation and proper identification of mushrooms, also when used in production of e.g. dried mushrooms or in ready-to-eat food.

\section{In-house control and documentation}

Establishing relevant documentation in the in-house control is an obligation in the trade and industry taking into account the legal requirements. Public food inspection can request it as part of their control.

Documentation can be described as:

- Declaration of compliance and

- Supporting background documentation

Declaration of compliance is normally the statement/certificate from a producer/exporter, while the supporting documentation would be the detailed information, e.g. on details of analysis like detection limits, methods, sampling or for mushrooms information on identification methods are qualification of experts involved in this. Furthermore, toxicological references could be part of the background documentation.

As such documentation is sometimes regarded as confidential, it should be assessable for public authority on request and used under normal confidentiality agreement. 


\section{Who should have in-house control?}

All links in the production chain from the grower or importer to the processing food industry to the restaurant and other retailers should have in-house control and relevant documentation. The private collectors should have adequate knowledge, preferable certified.

The producer, user or importer is responsible for observing the legal requirements of mushrooms, including processed and pre-packed mushroom products.

\section{Declarations of compliance and supporting background documentation}

Compliance shall be documented as part of the in-house declarations of compliance in industry and trade.

\section{The responsible companies shall have}

- Relevant knowledge of which mushrooms are edible and identification of them

- Relevant knowledge about the legislation in order to be able to assess the reliability of the documentation

- The starting point for the check lists for the establishment of appropriate inhouse documentation is that all links in the chain from the grower or collector of the mushrooms to the importers of dried mushrooms or the restaurants buying from private collectors take responsibility

- In-house documentation based on knowledge and trust between trade partners

In general, a declaration of compliance should as a starting point be regarded as adequate in-house documentation for mushrooms and mushroom products.

In this area of safe use of mushrooms as foods, the questionnaire is meant to be used to ensure valid documentation of the identity and safety of the mushrooms, and the lists are supporting this questionnaire. 



\section{Annex II - Addresses}

\section{Food Authorities in the Nordic countries}

Danish Veterinary and Food Administration (Fødevarestyrelsen): www.fvst.dk

Finnish Food Safety Authority Evira (Evira):

http://www.evira.fi

Icelandic Food and Veterinary Authority, MATIS (Matvælastofnun):

http://www.mast.is

Norwegian Food Safety Authority (Mattilsynet):

http://www.mattilsynet.no (information for trade an9d industry)

http://www.matportalen.no (information for the public)

Swedish National Food Agency (Livsmedelsverket):

http://www.slv.se

\section{National Poison Information Centres in the Nordic Countries}

In Denmark, Finland, Iceland and Sweden: Acute cases call 112, for Norway Acute cases call 113. In all countries, ask for poison information center in less severe cases contact the national poison information centre. See addresses and phone numbers below.

\begin{tabular}{ll}
\hline Denmark & Giftlinjen \\
& http://www.bispebjerghospital.dk/giftlinjen/forside/, \\
& Phone +4582121212 \\
& Myrkytystietokeskus \\
hinland & http://www.hus.fi/default.asp?path=1,28,824,2049,2265,2260 Giftinformationscentralen \\
& Poison Information Centre \\
& http://www.hus.fi/default.asp?path=59;403;19336;9739;9541 \\
& Phone + 358 9 47 19 77 \\
& Eitrunarmiðstöð \\
& http://www.landspitali.is/eitrunarmidstod \\
& Phone +358 543 2222 \\
Iceland & Giftinformasjonen \\
& www.giftinfo.no \\
Phone +47 22591300 & Note: Acute cases call 113 \\
& Giftinformation \\
http://www.giftinformation.se/ & Phone +46 (0)8 331231) \\
&
\end{tabular}




\section{Nordic, national societies on mushrooms}

\begin{tabular}{|c|c|}
\hline Denmark & $\begin{array}{l}\text { Danish Mycological Society } \\
\text { www.svampe.dk }\end{array}$ \\
\hline Finland & $\begin{array}{l}\text { Mycological Society of Finland } \\
\text { Suomen Sieniseura Ry, Unioninkatu } 44 \\
\text { SF 00170, Helsinki 17, Finland } \\
\text { http://www.funga.fi/ }\end{array}$ \\
\hline Island & $\begin{array}{l}\text { The Icelandic Institute of Natural History } \\
\text { Nátttúrufæðistofnun Íslands } \\
\text { Urriðaholtsstræti 6-8 } \\
210 \text { Garđabæ } \\
\text { www.ni.is }\end{array}$ \\
\hline Norway & $\begin{array}{l}\text { Norwegian Association of Fungi and Useful Plants } \\
\text { (Norges Sopp- og Nyttevekstforbund) } \\
\text { http://www.soppognyttevekster.no/ }\end{array}$ \\
\hline Sweden & $\begin{array}{l}\text { Sveriges Mykologisk Förening, Institutionen för växt- och miljövetenskaper } \\
\text { Göteborgs universitet, Box } 461 \\
40530 \text { Göteborg, Sverige } \\
\text { http://www.svampar.se/ }\end{array}$ \\
\hline
\end{tabular}


Nordic Council of Ministers

Ved Stranden 18

DK-1061 Copenhagen K

www.norden.org

\section{Mushrooms traded as food}

Mushrooms recognised as edible have been collected and cultivated for many years. In the Nordic countries, the interest for eating mushrooms has increased.

In order to ensure that Nordic consumers will be supplied with safe and well characterised, edible mushrooms on the market, this publication aims at providing tools for the in-house control of actors producing and trading mushroom products.

The report is divided into two documents:

a. Volume I: "Mushrooms traded as food - Nordic questionnaire and guidance list for edible mushrooms suitable for commercial marketing

b. Volume II: Background information, with general information in section 1 and in section 2, risk assessments of more than 100 mushroom species

All mushrooms on the lists have been risk assessed regarding their safe use as food, in particular focusing on their potential content of inherent toxicants. The goal is food safety. 